\title{
MENGALAMI ALLAH MELALUI KITAB MAZMUR $^{1}$
}

\author{
Sia Kok Sin
}

\begin{abstract}
Abstrak: Tulisan ini membahas penggunaan analisa bentuk sebagai upaya menemukan kekayaan kitab Mazmur untuk pembangunan kehidupan rohani orang percaya. Melalui Analisa Bentuk seseorang dapat menemukan keragaman bentuk mazmur-mazmur yang ada, di antaranya Mazmur Pujian, Mazmur Keluhan, Mazmur Ucapan Syukur, Mazmur Keyakinan, dan lain-lain. Tulisan ini memfokuskan pada 3 bentuk yang ada, yaitu Mazmur Pujian, Mazmur Keluhan dan Mazmur Ucapan Syukur. Mazmur Pujian merupakan ungkapan pujian dan keagungan kepada Allah dari pribadi atau komunal oleh karena merenungkan karakter Allah dan karya Allah yang umum, seperti penciptaan, penyelamatan, dan lain-lain. Mazmur Keluhan tidak hanya merupakan ungkapan keluhan pemazmur baik secara pribadi, maupun komunal di tengah pelbagai persoalan dan kesulitan hidup, namun sering kali disertai dengan doa, ungkapan kepercayaan kepada Allah dan tekad untuk memuji Allah. Mazmur Ucapan Syukur merupakan ungkapan syukur yang lahir oleh karena pengalaman pertolongan Allah yang nyata dalam kehidupan pemazmur. Ketiga bentuk Mazmur ini perlu digunakan dalam kekayaannya dalam upaya membangun kerohanian dan ibadah umat, sehingga umat mempunyai pengalaman bersama dengan Allah yang Alkitabiah, sehat dan aktual.
\end{abstract}

Kata-kata Kunci: Kitab Mazmur, Analisa Bentuk, Mazmur Pujian, Mazmur Keluhan, Mazmur Ucapan Syukur, Kerohanian dan Ibadah

Abstract: The purpose of this study is to use the form (genre) criticism in exploring the richness of the book of Psalms. By using the form criticism, some one can find that there are many forms in the book of Psalms, such as the Psalms of Praise, the Psalms of Lament, the Psalms of

Artikel ini disampaikan dalam Summa Lectura 3, Jakarta, 18-19 April 2016. 
Thanksgiving, The Psalms of Confidence, etc. This study focus on the the Psalms of Praise, the Psalms of Lament, and the Psalms of Thanksgiving. These three form of the Psalms can enrich God's people in building the true and healthy of spritual life and worship.

Keywords: The book of Psalms, Form Criticism, The Psalms of Praise, The Psalms of Lament, The Psalms of Thanksgiving, Spiritual Life and Worship

\section{ISTILAH "KITAB MAZMUR"}

Dalam Alkitab bahasa Indonesia kitab ini disebut sebagai Mazmur. Istilah "Mazmur" berasal dari kata מִזמוֹ ( mizmôr ), yang berarti nyanyian atau nyanyian yang diiringi dengan alat musik. ${ }^{2}$ Alkitab bahasa Inggris menyebut kitab ini sebagai Psalms dari kata $\psi \alpha \lambda \mu o i ́$ yang berarti מִזמוֹר (mizmôr) ini sering diterjemahkan dalam kata Yunani $\psi \alpha \lambda \mu$ oí, ${ }^{4}$ sehingga dapat disimpulkan bahwa penerjemah Alkitab bahasa Indonesia dan Inggris memahami kitab ini sebagai kumpulan nyanyian, khususnya nyanyian yang digunakan dalam ibadah. Sedangkan ada komunitas Yahudi menyebut kitab ini sebagai (těhillim) yang berarti "nyanyian-nyanyian pujian."

Hans-Joachim Kraus berpendapat bahwa istilah חת (těhillim) ini tidaklah terlalu tepat, karena tidak semua (150 pasal) merupakan nyanyian pujian. ${ }^{6}$ Marie Claire Barth dan B.A. Pareira juga sependapat dengan Kraus, dengan alasan bahwa kitab Mazmur ini terdiri dari pelbagai jenis nyanyian dan doa, seperti permohonan, pernyataan kepercayaan dan renungan. ${ }^{7}$ Sedangkan Gerald H. Wilson berpendapat

\footnotetext{
Hans-Joachim Kraus, Psalms 1-59 (Minneapolis: Augsburg Publishing House, 1988), p. 22.

Ibid., p.12.

Ibid.

Ibid., p.11.

Ibid.

Marie Claire Barth dan B.A. Pareira, Kitab Mazmur 1-72 (Jakarta: BPK, 1997), h.20.
} 
bahwa istilah ini tetap tepat, karena struktur kitab Mazmur itu bergerak dari ratapan yang mendominasi bagian pertama kitab Mazmur menuju kepada pujian yang mendominasi bagian kedua kitab Mazmur. ${ }^{8}$ Komunitas Yahudi yang lebih awal menyebut kitab ini sebagai (Têpillâ) yang berarti doa, dengan pertimbangan bahwa nyanyian dan doa ratapan merupakan bagian besar dari kitab ini. ${ }^{9}$

Dalam kaitan dengan hal ini penulis berpendapat bahwa istilah "Mazmur" atau "Psalms" lebih tepat digunakan sebagai sebutan untuk kitab ini, karena istilah " Mazmur" atau "Psalms" lebih netral dan luas, karena istilah ini mewakili nyanyian rohani atau nyanyian yang digunakan dalam ibadah, dan tidak menunjukkan kepada jenis atau genre terlalu spesifik, seperti nyanyian pujian (song of praise), ataupun doa.

\section{PENTINGNYA KITAB MAZMUR}

Pentingnya kitab Mazmur bagi kehidupan umat percaya diakui oleh pelbagai ahli. Philip Johnston dan David Firth mengungkapkan,

"The book of Psalms is the best loved and most treasured book of the Hebrew Scriptures. It has been precious to countless thousand of faithful Jewish and Christian believers in hundreds of different languages and countries over several millennia, expressing their hopes and fears, inspiring their faith, and renewing their trust in God. ${ }^{, 10}$

Eric Peels mengungkapkan bahwa kalau narasi dalam Perjanjian Lama itu berkaitkan dengan apa yang Allah telah kerjakan, tulisan nabinabi itu melaporkan apa yang telah Allah sabdakan, sedangkan Mazmur adalah tanggapan umat atas karya dan sabda Allah, bahkan ketika Allah nampaknya inaction dan berdiam. ${ }^{11}$ Seluruh pengalaman kehidupan

8 Gerald H. Wilson, "The Structure of the Psalter," Interpreting the Psalms. Edited by Philip S. Johnston dan David G. Firth (Downers Grove: IVP Academic, 2005), p.246.

9 Kraus, Psalms 1-59, p.11.

10 Philip Johnston dan David Firth, "Introduction," Interpreting the Psalms. Edited by Philip S. Johnston dan David G. Firth (Downers Grove: IVP Academic, 2005), p.17.

11 Eric Peels, "Introduction," Psalms and Prayers. Papers Read at the Joint Meeting of the Society of Old Testament Study and Het Oudtestamentisch Werkgezelschap in 
manusia nampak dalam Mazmur menyebabkan bahwa kitab ini sangat bermanfaat dalam ibadah umum, ibadah keluarga dan perenungan pribadi. ${ }^{12}$ Bentuk dasar Mazmur yang terdiri dari pujian dan doa, hymne dan ratapan merefleksikan polaritas kehidupan manusia yang meliputi saat baik dan buruk, putus ada dan penuh harapan, sukacita dan duka cita. $^{13}$

Tremper Longman III mengungkapkan bahwa kitab Mazmur merupakan suatu tempat pertemuan antara Allah dan manusia, di mana umat menyapa Allah melalui pujian dan keluhan yang semuanya itu menunjukkan nuansa langsung, hangat, intim dan jujur. ${ }^{14}$ Kitab Mazmur ini dapat menyapa seseorang dalam totalitasnya, karena kitab ini memberikan informasi kepada intelek, membangkitkan emosi, memimpin kehendak dan merangsang imajinasi seorang yang membacanya. ${ }^{15}$

Jadi kitab Mazmur merupakan suatu kitab yang sangat penting untuk dibaca dan dipelajari, sehingga seseorang boleh mengalami Allah dalam pelbagai spektrum pengalaman kehidupannya.

\section{TREND STUDI MAZMUR}

David M. Howard, Jr. mengungkapkan bahwa beberapa dekade terakhir ini studi Mazmur menitikberatkan pendekatan sastra dan kanonik. ${ }^{16}$ Studi Mazmur dengan pendekatan sastra melakukan penyelidikan lebih mendalam karakteristik puisi Ibrani, khususnya berkaitan paralelisme dengan beberapa tokohnya, seperti Adele Berlin, James Kugel dan Robert Alter. ${ }^{17}$ Pendekatan sastra ini juga memperdalam penggunaan analisa bentuk dalam studi Mazmur yang telah dipelopori

Nederland en België, Apeldoorn August 2006. Edited by Bob Becking and Eric Peels (Leiden: Brill, 2007), p.1.

12 Eric Peels, "Introduction," Psalms and Prayers, p.1.

13 Ibid.

14 Tremper Longman III, Bagaimana Menganalisa Kitab Mazmur? (Malang: SAAT, 1994), h.3.

15 Ibid., h.5.

16 David M. Howard, Jr., "The Psalms and Current Study," Interpreting the Psalms. Edited by Philip S. Johnston dan David G. Firth (Downers Grove: IVP Academic, 2005), p. 23.

17 Ibid., p.30-32. 
oleh Herman Gunkel, ${ }^{18}$ dan dilanjutkan oleh tokoh-tokoh lainnya, seperti Sigmund Mowinckel, Claus Westermann, Erhard Gerstenberger, Walter Brueggemann, dan lain-lain. ${ }^{19}$ Sedangkan studi Mazmur dengan pendekatan kanonik berupaya memahami kitab Mazmur sebagai satu buku utuh yang susunannya mempunyai tujuan tertentu dan tidak acak. ${ }^{20}$ Beberapa tokoh dengan pendekatan ini adalah Brevard Childs, Gerald H. Wilson, Erich Zenger, N. Whybray, dan lain-lain. ${ }^{21}$

Dalam tulisan ini penulis memfokuskan penggunaan analisa bentuk untuk memahami bagian kitab Mazmur. ${ }^{22}$ Oleh karena itu pertama-tama penulis akan mengungkapkan secara umum pendekatan analisa bentuk sebagai salah satu upaya memahami kitab Mazmur dan selanjutnya akan membahas lebih mendalam Mazmur Pujian, Ratapan dan Ucapan Syukur.

\section{ANALISA BENTUK UNTUK MEMAHAMI KITAB MAZMUR}

H. Gunkel (1862-1932) dianggap sebagai pakar yang pelopor dan tokoh utama yang menggunakan analisa bentuk dalam penyelidikan kitab Mazmur, ${ }^{23}$ walau ada ahli yang mengungkapkan bahwa Eusebius telah

\footnotetext{
Howard, Jr., "The Psalms and Current Study," Interpreting the Psalms, p.36-39.

Ibid.

Ibid., p.24-29.

Ibid.

22 Penulis mengamati bahwa di Indonesia penggunaan pendekatan analisa bentuk di Indonesia " belum terlalu banyak" diperhatikan untuk memahami kitab Mazmur. Pendekatan yang umum adalah bersifat historis, yaitu mengupayakan penemuan latar belakang historis dari suatu Mazmur yang diselidiki, khususnya dari sejarah kehidupan Daud.

23 W.D. Tucker, Jr., "Psalms 1: Book of," Dictionary of the Old Testament. Wisdom, Poetry \& Writings (Downers Grove, IVP Academic, 2008), 580, Kraus, Psalms 1-59, 38. H. Gunkel dianggap sebagai pelopor penggunaan analisa bentuk dalam studi Alkitab. Band. M.A. Sweeney, "Form Criticism," Dictionary of the Old Testament. Wisdom, Poetry \& Writings (Downers Grove, IVP Academic, 208), p.229-30. Adapun penerapan analisa bentuk dalam suatu teks Alkitab meliputi 4 bagian, yaitu:

1. Analisa struktur atau garis besar teks

2. Identifikasi genre teks

3. Analisa kedudukan kehidupan (Sitz im Leben) genre teks

4. Identifikasi tujuan dan fungsi (intention) genre teks.

Band. Sia Kok Sin, "Analisa Bentuk Sebagai Salah Satu isi Kontemporer Dalam Penafsiran Perjanjian Lama,” Jurnal Theologi Aletheia 1/2 (Maret 1996), h.108-10.
} 
menyadari adanya pelbagai bentuk mazmur. ${ }^{24}$ Sebelum berkembangnya penggunaan analisa bentuk para ahli menggunakan pendekatan kritik historis dalam upaya menempatkan suatu Mazmur tertentu dalam konteks historis yang spesifik. ${ }^{25}$ Sejak itu studi kitab Mazmur selalu memberi perhatian kepada analisa bentuk yang berupaya untuk memahami pelbagai genre dalam kitab Mazmur.

Sebuah genre dapat diartikan sebagai " sebuah kelompok ayat-ayat yang sama dalam mood, isi, struktur atau susunan kata-katanya."26 Penerapan analisa bentuk dalam studi kitab Mazmur menyadarkan bahwa kitab Mazmur ini terdiri dari pelbagai genre. Pemahaman akan genre ini tidak hanya menolong seseorang dalam memahami suatu Mazmur, tetapi juga menolong untuk memahami kebanyakan Mazmur tanpa harus mempelajari Mazmur itu satu persatu. ${ }^{27}$

Dalam bagian ini hanya dipilih beberapa ahli yang mewakili untuk memberikan gambaran umum pembagian dan pendefinisian pelbagai genre kitab Mazmur, yaitu Hermann Gunkel, Erhard Gerstenberger, Tremper Longman III, Marie Claire Barth dan B.A. Pareira. ${ }^{28}$ Sedangkan pembahasan lainnya tentang penggunaan analisa bentuk dalam studi kitab Mazmur pendapat para ahli lainnya juga disertakan dan dibahas.

24 Karlfried Froehlich menyatakan bahwa Eusebius dalam komentarnya tentang kitab Mazmur mengungkapkan bahwa tidak semua mazmur mempunyai bentuk yang sama: beberapa adalah hymne, beberapa adalah ratapan, beberapa adalah puisi teologis, beberapa adalah nubuatan atau ramalan. Karlfried Froehlich, "Discerning the Voices: Praise and Lament in the Tradition of the Christian Psalter," Calvin Theological Journal, 36 (2001), p.82.

25 Tucker, Jr., "Psalms 1: Book of," Dictionary of the Old Testament. Wisdom, Poetry \& Writings, p.580.

26 Tremper Longman III, Bagaimana Menganalisa Kitab Mazmur? (Malang: SAAT, 1994), h.10.

27 Ibid., p.14.

28 Hermann Gunkel dipilih oleh karena ia pelopor pendekatan ini, Erhard Gerstenberger dipilih oleh karena karyanya tentang kitab Mazmur dengan penggunaan analisa bentuk dalam seri FOTL (the Forms of the Old Testament Literature), Tremper Longman III dipilih sebagai wakil Teolog Amerika dan karyanya telah diterjemahkan dalam bahasa Indonesia dan Marie Claire Barth dan B.A. Pareira dipilih sebagai karya dalam bahasa Indonesia. 
Herman Gunkel menyatakan ada beberapa genre dalam kitab Mazmur, yaitu Hymne, ${ }^{29}$ Ratapan Komunal, ${ }^{30}$ Nyanyian Syukur Individu, ${ }^{31}$ Nyanyian Ratapan Rohani Individu, ${ }^{32}$ Pelbagai Bentuk Campuran (Liturgi untuk Masuk/Litugy of Entrance, Nyanyian-nyanyian Taurat) ${ }^{33}$, dan Mazmur Raja. ${ }^{34}$

\author{
Erhard Gerstenberger ${ }^{35}$ mengategorikan Mazmur-mazmur ini \\ sebagai Keluhan (Complaints) ${ }^{36}$, Ucapan Syukur (Thanksgivings) ${ }^{37}$, Puji-
}

29 Hymne adalah nyanyian pujian (Ibrani - tehillah dari hillel, yang artinya menyanyi lagu pujian). Hymne ini biasanya dimulai dengan ajakan seorang pemimpin ibadah kepada jemaah, seperti Bersyukurlah (Mazmur 105:1), Pujilah TUHAN (Mazmur 104:1), Bersorak-sorailah (Mazmur 33:1), dan lain-lain. Kemudian bagian Hymne ini dilanjutkan dengan hal-hal yang menjadi alasan untuk memuji, seperti sifat atau karya Allah. Hermann Gunkel, The Psalms. A Form-Critical Introduction (Philadelphia: Fortress Press, 1967), p.10-12.

30 Ratapan Komunal ini merupakan ratapan yang menggambarkan keadaan umat yang menyedihkan, oleh karena kegagalan panen, wabah dan bahaya serangan para musuh serta membawa umat untuk berkumpul di tempat ibadah untuk merobek jubah mereka, berpuasa, menangis dan meratap. Ratapan Komunal ini dapat dibagi tiga bagian, pertama, ratapan umat dengan harapan dapat menggerakkan belas kasihan Tuhan; kedua, keluhan terhadap para musuh; dan ketiga, doa kepada Tuhan agar malapetaka yang mereka alami dapat segera dihilangkan. Gunkel, The Psalms, p.13, 32.

31 Nyanyian (Syukur) Individu ini adalah nyanyian yang dinyanyikan oleh seorang yang saleh dalam konteks ibadah. Munculnya ungkapan " aku " dalam Mazmur-mazmur ini, yang oleh Gunkel dianggap dapat saja merupakan personifikasi yang mewakili suatu komunitas. Gunkel, The Psalms, p.15-17., p.32-33.

32 Gunkel mengungkapkan bahwa genre ini merupakan genre yang paling banyak dalam kitab Mazmur. Pemazmur meratap atas keberadaan sebagai orang miskin, tertekan dan tertindas serta mengeluh atas penindasan yang dilakukan oleh musuhnya. Gunkel, The Psalms, p.33.

Liturgi Untuk Masuk, seperti Mazmur 15. Gunkel, The Psalms, p.22.

Mazmur ini berkaitan dengan raja, seperti Mazmur 2, 18, 20, 21, dan lain-lain.

Gunkel, The Psalms, p.23-24.

35 Erhard Gerstenberger menghasilkan karya tentang Mazmur dengan pendekatan analisa bentuk dalam Psalms Part 1 with an Introduction to Cultic Poetry (Grand Rapids: Wm. B. Eerdmans Publishing Company, 1991) dan Psalms, Part 2, and Lamentations (Grand Rapids: Wm. B. Eerdmans Publishing Company, 2001). Mazmur Keluhan ini baik secara individu, maupun kolektif merupakan upaya mengadukan persoalan dan penderitaan yang dihadapi kepada Tuhan. Pelbagai penyebab penderitaan yang dialami oleh seseorang seperti penyakit parah, kemalangan atau yang dialami komunitas seperti musuh, kekeringan wabah atau hal jahat yang berbahaya lainnya. Genre ini tidak hanya berisikan permohonan atau ratapan saja, tetapi juga suatu " tuntutan " tanggung jawab Allah atas penderitaan yang terjadi. Juga sering disertai dengan Janji dan Tekad Ucapan Syukur sebagai 
pujian (Songs of Praise/Hymns) ${ }^{38}$, Mazmur Raja (Royal Psalms) ${ }^{39}$ dan Mazmur Hikmat (Wisdom Psalms). ${ }^{40}$

Tremper Longman III berpendapat bahwa ada tujuh macam genre Mazmur, yaitu Mazmur Pujian, ${ }^{41}$ Mazmur Keluhan, ${ }^{42}$ Mazmur

respon terhadap keyakinan akan pertolongan Allah. Gerstenberger, Psalms Part 1, p.11-13.

37 Nyanyian Ucapan Syukur ini merupakan nyanyian yang dipersembahkan sebagai ucapan syukur oleh karena pemazmur telah mengalami pertolongan Allah dari bahaya dan kesengsaraan. Gerstenberger, Psalms Part 1, p.14-15.

38 Pujian-pujian ini merupakan ungkapkan pujian hanya kepada Yahweh yang menciptakan dan memelihara alam semesta, berkarya dalam kehidupan umat-Nya. Gerstenberger, Psalms Part 1, p.16-18. Mazmur Raja adalah mazmur yang berkaitan Yahweh sebagai Sang Raja ataupun dinasti Daud yang memerintah sebagai raja Israel. Gerstenberger, Psalms Part 1, p.19. Mazmur Hikmat adalah mazmur yang berkaitkan dengan pentingnya Taurat yang mengajarkan umat untuk hidup menaati Taurat dan tidak hidup sebagai orang fasik. Gerstenberger, Psalms Part 1, p.19-21.

41 Mazmur Pujian ini dapat dikenal melalui ungkapan-ungkapan penuh sukacita yang ditujukan kepada Tuhan. Pemazmur mengungkapkan semua perasaannya dengan penuh sukacita atas kehadiran dan kebaikan Tuhan. Mazmur ini biasanya dimulai dengan ajakan untuk menyembah atau memuji Tuhan, kemudian dilanjutkan dengan uraian alasan mengapa Tuhan patut dipuji dan kadang-kadang juga diakhiri dengan ajakan lebih lanjut untuk memuji Tuhan. Tremper Longman III, Bagaimana Menganalisa Kitab Mazmur? (Malang: SAAT, 1994), h.15-18.

42 Mazmur Keluhan ini merupakan ungkapan tangisan kesediaan pemazmur yang mana ia merasa tidak ada tempat lain untuk mengeluh selain kepada Tuhan. Mazmur Keluhan ini dapat mempunyai tujuh bagian, seperti: doa, permohonan minta tolong kepada Tuhan, keluhan-keluhan, pengakuan dosa atau pernyataan tidak bersalah, kutukan pada musuh-musuh, keyakinan pada respons Tuhan dan pujian atau berkat. Mazmur Keluhan ini dapat dibedakan menjadi keluhan pribadi (Mazmur 3) atau keluhan nasional (Mazmur 83). Longman III, Bagaimana Menganalisa Kitab Mazmur?, h.18-23. 


\title{
Pengucapan Syukur, ${ }^{43}$ Mazmur Keyakinan, ${ }^{44}$ Mazmur Peringatan, ${ }^{45}$ Mazmur Hikmat ${ }^{46}$ dan Mazmur Raja. ${ }^{47}$
}

\author{
Marie Claire Barth dan B.A. Pareira mengategorikan jenis Mazmur \\ dalam empat bagian besar, yaitu Pujian (madah, madah "TUHAN Raja", \\ nyanyian Sion) ${ }^{48}$, Doa (permohonan, kepercayaan, ucapan syukur), ${ }^{49}$
}

43 Mazmur Ucapan Syukur adalah Mazmur yang berisikan suatu respon ucapan syukur oleh karena pemazmur telah mendapat jawaban Tuhan atas keluhannya atau jawaban doa dari Tuhan. Longman III, Bagaimana Menganalisa Kitab Mazmur?, h.24.

44 Mazmur Keyakinan ini merupakan ungkapan keyakinan pemazmur kepada Tuhan ataupun ungkapan penyerahannya kepada Tuhan, meskipun ia harus menghadapi musuh dan ancaman. Longman III, Bagaimana Menganalisa Kitab Mazmur?, h.2526.

45 Mazmur Peringatan ini adalah Mazmur yang berisikan referensi terhadap sejarah karya penebusan Tuhan di masa lampau yang mana mendorong umat untuk memuji dan bersyukur kepada Tuhan. Longman III, Bagaimana Menganalisa Kitab Mazmur?, h.26-27.

46 Mazmur Hikmat adalah Mazmur yang menggambarkan kontras cara hidup antara orang benar dan orang fasik. Mazmur Hikmat ini juga berkaitan dengan tema tentang Taurat atau hukum Tuhan. Longman III, Bagaimana Menganalisa Kitab Mazmur?, h.28. Mazmur ini berkaitkan dengan raja Israel ataupun refleksi dan pujian Tuhan sebagai raja. Longman III, Bagaimana Menganalisa Kitab Mazmur?, h.29-30.

48 Pujian terdiri dari 3 jenis, yaitu Madah, Madah "TUHAN Raja" dan Nyanyiannyanyian Sion. Madah adalah jenis Mazmur yang mengagungkan Tuhan karena kebesaran dan kemuliaan-Nya atas segala karya-karya-Nya. Madah ini dijiwai oleh perasaan sukacita, penyembahan dan pengagungan akan Tuhan. Madah " TUHAN Raja” berisikan puji-pujian Tuhan sebagai Raja Israel dan alam semesta, yang mengajak bangsa Israel dan bangsa-bangsa lain untuk memuji dengan sukacita Tuhan sebagai Raja. Nyanyian-nyanyian Sion Mazmur berisikan nyanyian-nyanyian yang mengagungkan Tuhan karena pilihan dan perlindungan-Nya atas Yerusalem dan kehadiran-Nya yang menyelamatkan di kota Sion. Barth dan Pareira, Kitab Mazmur 1-72, h.52-58.

49 Doa ini terdiri dari permohonan, kepercayaan dan ucapan syukur. Doa Permohonan merupakan jenis mazmur yang paling banyak dan kurang lebih jumlah sepertiga dari kitab Mazmur. Jenis mazmur ini juga disebut sebagai " ratapan " atau " keluh kesah ". Doa Permohonan ini dapat bersifat Perseorangan ataupun Jemaah. Doa Kepercayaan adalah ungkapan kepercayaan yang di dalamnya nampak ketenangan hati, kedamaian dan kekuatan di tengah pelbagai kesukaran dan tantangan hidup. Doa Kepercayaan ini dapat dibagi menjadi Doa Kepercayaan Perseorangan dan juga Doa Kepercayaan Jemaah. Doa ucapan Syukur ini merupakan ucapan syukur yang dinaikkan oleh perseorangan atau jemaah oleh karena permohonannya telah didengar dan dibebaskan dari penderitaan. Barth dan Pareira, Kitab Mazmur 1-72, h.59-67. 
Mazmur Raja ${ }^{50}$, Pengajaran (kebijaksanaan, mazmur sejarah, mazmur kenabian, liturgi). ${ }^{51}$

Melalui pemaparan singkat di atas, dapat ditemukan pelbagai pendapat para ahli dalam pengategorian genre dalam kitab Mazmur. Para ahli dapat mempunyai kesamaan dan juga perbedaan dalam pengategorian genre suatu Mazmur. ${ }^{52}$ Seseorang harus berhati-hati dan tidak boleh kaku dalam pengategorian genre dalam kitab Mazmur, karena ada Mazmur yang dapat dikategorikan dalam beberapa genre. ${ }^{53}$

Hal yang sulit dalam pendekatan analisa bentuk dalam studi kitab Mazmur adalah penentuan Sitz im Leben (Life Setting/Situasi Kehidupan) dari Mazmur ini. ${ }^{54}$ Hal ini nampak dari pelbagai pendapat para ahli tentang hal ini.

Herman Gunkel berpendapat bahwa tiap bentuk nyanyian tertentu digunakan dalam kaitan dengan situasi tertentu. ${ }^{55}$ Nyanyian pujian (hymns) digunakan untuk perayaan hari-hari besar keagamaan. ${ }^{56}$

50 Mazmur-mazmur ini dikelompokkan menjadi satu, oleh karena kesamaan temanya, yaitu tentang raja. Oleh karena raja-raja dari dinasti Daud itu erat hubungannya dengan kerajaan Tuhan dan Sion, maka Mazmur-mazmur Raja ini harus dipahami dalam hubungannya dengan madah " Tuhan Raja” dan "Nyanyian-nyanyian Sion”. Barth dan Pareira, Kitab Mazmur 1-72, h.67-68.

51 Pengajaran ini terdiri Kebijaksanaan, Mazmur Sejarah, Mazmur Kenabian dan Liturgi. Mazmur Kebijaksanaan mempunyai gaya dan isi seperti sastra hikmat. Mazmur ini menekankan pentingnya Taurat, perbandingan antara orang benar dan orang fasik, dan juga berkat bagi orang yang takut akan Tuhan. Mazmur Sejarah ini menceritakan ulang sejarah karya Allah kepada Israel yang bermula dari panggilan dan pemilihan bapak leluhur bangsa, pembebasan dari perbudakan Mesir dan kehidupan di tanah perjanjian baik masa hakim-hakim, maupun para raja. Tujuan Mazmur Sejarah ini adalah pengajaran. Mazmur Kenabian mempunyai gaya dan isinya seperti pemberitaan para nabi yang menyampaikan penghakiman dan penghukuman kepada Israel. Mazmur Liturgi mempunyai unsur tanya-jawab dalam kaitan dengan liturgi ibadah. Barth dan Pareira, Kitab Mazmur 1-72, h.68-71.

Band. Philip S. Johnston, "APPENDIX 1: INDEX OF FORM CRITICAL CATEGORIZATIONS," Interpreting the Psalms. Edited by Philip S. Johnston dan David G. Firth (Downers Grove: IVP Academic, 2005), p.295-300. Longman III, Bagaimana Menganalisa Kitab Mazmur?, h.30. Gerstenberger mengungkapkan bahwa studi tentang Sitz im Leben ini masih butuh penyelidikan yang lebih jauh. Gerstenberger, Psalms Part 1, p.xv. 
Nyanyian pujian itu seperti suatu persembahan atau kurban. ${ }^{57}$ Sedangkan ratapan komunal digunakan pada hari-hari perkabungan umat oleh karena kegagalan panen, hama dan bahaya penindasan dari musuh. ${ }^{58}$ Ada juga nyanyian kurban syukur yang dinyanyikan oleh seseorang yang telah diselamatkan dari bahaya besar, seperti kesembuhan dari sakit, dan lainlain. ${ }^{59}$ Selanjutnya Gunkel juga membahas tentang ratapan individu yang lahir oleh karena pengalaman antara hidup dan mati yang disebabkan oleh penyakit, ataupun pelbagai tekanan berat yang disebabkan aniaya atau fitnah para musuh. ${ }^{60}$ Ada juga nyanyian-nyanyian yang digunakan sebagai liturgi yang menyiapkan umat untuk datang ke Bait Suci (the Liturgy of Entrace). ${ }^{61}$ Sedangkan Mazmur Raja juga terkait erat dengan tempat suci dari kerajaan, seperti Yerusalem, Betel, dan Dan. ${ }^{62}$

Gunkel berpendapat bahwa puisi keagamaan Israel yang merupakan bagian dari ibadah tumbuh di kalangan para iman yang mempelajari puisi-puisi ini sejak masa kanak-kanak dan mengetahui bagaimana penggunaannya dengan cara yang tepat. ${ }^{63}$ Selanjutnya Gunkel juga mengungkapkan adanya mazmur-mazmur yang muncul bukan dalam konteks atau upacara-upacara kultus , tetapi lahir dari kalangan orang saleh yang menyanyikan atau menjadikan sebagai doa di saat-saat tertentu, khususnya dalam era pasca pembuangan. ${ }^{64}$

Jadi dapat diringkas bahwa Gunkel berpendapat Sitz im Leben ini dari mazmur-mazmur yang ada ini umumnya muncul dalam konteks ibadah dan para imam, tetapi ada juga yang lahir dalam konteks kehidupan pribadi orang saleh.

Erhard Gerstenberger mengungkapkan bahwa mazmur-mazmur ini melayani kebutuhan komunitas keagamaan. ${ }^{65}$ Manusia sejak dahulu telah

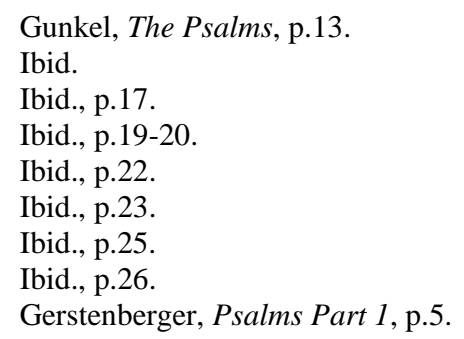


menyadari kekuatan kata-kata yang diucapkan dengan intonasi dan unsurunsur musik, seperti nyanyian, alat musik dan ritme, oleh karena manusia " primitif" pun telah menyanyikan doa-doa mereka. ${ }^{66}$ Seseorang tidak boleh melupakan dimensi psikologis, sosial, dan spiritual dalam pelbagai ibadah. ${ }^{67}$ Selanjutnya Gerstenberger mengungkapkan sulitnya untuk merekonstruksi sejarah kultus Israel, oleh karena tiap tahapan dalam sejarah iman, Israel mengembangkan pola ritual yang khas sebagai tanggapan terhadap kondisi sosial dan upaya penghargaan terhadap warisan rohani. ${ }^{68}$ Gerstenberger menyatakan bahwa kemungkinan ritual keagamaan Israel berkaitan dengan siklus iklim tahunan (the yearly cycle of the seasons), siklus kehidupan manusia (the life cycle of individual), yang di antaranya kelahiran, sunat, pernikahan dan kematian; kejadian yang spontan yang melahirkan ritual ("spontanaeous" rituals), seperti bencana yang melahirkan puasa komunal ataupun ratapan komunal, dan lain-lain. ${ }^{69}$ Jadi nampaknya Gerstenberger menekankan Sitz im Leben mazmur dalam konteks kultus Israel.

Tremper Longman III tidak banyak membahas tentang Sitz im Leben. Ia mengungkapkan bahwa mazmur-mazmur ini digunakan oleh orang-orang Israel yang saleh dalam ibadah secara pribadi ataupun umum. $^{70}$ Ada juga mazmur-mazmur yang digunakan untuk perayaanperayaan keagamaan tertentu. ${ }^{71}$

Marie Claire Barth dan B.A. Pareira berpendapat bahwa mazmur yang terutama bukanlah doa para imam atau para pemimpin bangsa, tetapi lebih merupakan doa orang perseorangan sebagai anggota umat Allah dalam persoalannya sehari-hari. ${ }^{72}$ Mazmur-mazmur ini berakar

\footnotetext{
Gerstenberger, Psalms Part 1, p.5.

Ibid., p.5-6.

68 Gerstenberger membagi secara umum sejarah Israel sebagai Israel awal yang hidup sebagai masyarakat semi-nomaden, Israel yang hidup di Kanaan sebagai masyarakat pertanian, Israel di zaman kerajaan dan Israel pada masa pembuangan dan pemulihan. Gerstenberger, Psalms Part 1, p.7.

69 Gerstenberger, Psalms Part 1., p.8-9.

70 Longman III, Bagaimana Menganalisa Kitab Mazmur?, h.46.

71 Ibid., h.49.

72 Barth dan Pareira, Kitab Mazmur 1-72, h.14.
} 
dalam ibadah yang dirayakan di Yerusalem. $^{73}$ Ibadah di Bait Suci diadakan dalam kaitan dengan hari raya besar (seperti Paskah dan Pondok Daun) ataupun ada kejadian khusus (seperti musuh, bencana, pelantikan raja, dan lain-lain.), walaupun ada juga yang dalam konteks di luar Bait Suci. $^{74}$

Jadi dapat diringkas bahwa secara umum para ahli berpendapat bahwa Sitz im Leben mazmur-mazmur ini adalah ibadah, yang mana mazmur-mazmur ini digunakan dalam konteks ibadah baik secara pribadi, maupun umum.

\section{FOKUS PADA MAZMUR PUJIAN, MAZMUR KELUHAN DAN MAZMUR UCAPAN SYUKUR.}

Pertanyaan pertama dalam Katekismus Besar Westminster adalah:

Pertanyaan: Apa tujuan utama dan tertinggi manusia?

Jawaban: Tujuan utama dan tertinggi manusia ialah memuliakan Allah dan bersuka cita sepenuhnya di dalam Dia untuk selama-lamanya. ${ }^{75}$

Melalui hal ini nampaklah bahwa tujuan manusia diciptakan, berada dan berkarya di dunia ini adalah memuliakan Allah, hidup penuh syukur dan menikmati kehidupan yang penuh sukacita bersama dengan Allah. Namun realita dan pengalaman hidup manusia sepanjang zaman tidak hanya ditandai dengan ungkapan-ungkapan memuliakan Allah, ucapan-ucapan syukur kepada Allah ataupun kesaksian tentang hidup yang berbahagia. Realita dan pengalaman hidup manusia tidak jarang justru ditandai dengan kesedihan, penderitaan, ratapan, keluhan dan sejenisnya. Oleh karena itu dapat disimpulkan bahwa memang kehidupan manusia itu idealnya ditandai dengan pujian dan ucapan syukur, namun realita kehidupan manusia tidak dapat terlepas dari keluhan atau ratapan. Pengalaman hidup manusia baik yang ideal, maupun yang lebih realistis nampak dalam kitab Mazmur.

\footnotetext{
73 Barth dan Pareira, Kitab Mazmur 1-72, h.15.

74 Ibid., h.16-19.

75 Th. van den End, "Katekismus Besar Westminster," Enam Belas Dokumen Dasar Calvinisme (Jakarta: BPK, 2000), h.251.
} 
Menurut penulis ada 3 genre dalam kitab Mazmur yang dapat mewakili spektrum pengalaman hidup manusia itu, yaitu: Mazmur Pujian, Mazmur Ucapan Syukur dan Mazmur Keluhan.

\section{MAZMUR PUJIAN}

Mazmur Pujian ini dapat dikenal melalui ungkapan-ungkapan penuh sukacita yang ditujukan kepada Tuhan dan pemazmur mengungkapkan semua perasaannya dengan penuh sukacita atas kehadiran dan kebaikan Tuhan. ${ }^{76}$ Walau liturgi Israel disertai dengan nyanyian, musik, sorak-sorai, tepuk-tangan dan bahkan tari-tarian, namun pujian yang penuh sukacita itu, namun tetap ada penyembahan dan takut yang sangat dalam akan keagungan Tuhan. ${ }^{77}$ Gunkel mengungkapkan bahwa "the predominat mood in all the Hymns is the enthusiastic but reverent adoration of the glorious and awe-inspiring God.",78

Erhard Gerstenberger menyatakan bahwa Mazmur Pujian ini terdiri dari empat bagian utama, yaitu: ${ }^{79}$

1. Seruan kepada Yahweh

2. Ajakan Untuk Memuji atau Menyembah

3. Alasan Untuk Memuji atau Menyembah: karya, perbuatan dan karakter-Nya

4. Berkat atau Harapan.

Sedangkan Longman III mengungkapkan bahwa secara umum Mazmur Pujian mempunyai struktur, seperti:

1. Dimulai ajakan untuk menyembah atau memuji Tuhan

2. Dilanjutkan dengan uraian tentang alasan untuk menyembah atau memuji Tuhan

Longman III, Bagaimana Menganalisa Kitab Mazmur?, h.15.

Barth dan Pareira, Kitab Mazmur 1-72, h.52-53.

Gunkel, The Psalms, p.13.

Gerstenberger, Psalms Part 1, p.17. 
3. Kadang-kadang diakhiri dengan ajakan lebih lanjut untuk menyembah atau memuji Tuhan. ${ }^{80}$

Barth dan Pareria mengungkapkan bahwa Mazmur Pujian itu tersusun sebagai berikut:

1. Undangan atau pernyataan maksud pengarang untuk memuji Tuhan sebagai pembukaan.

2. Motif pujian: ini merupakan unsur pokok

3. Penutup: dapat berupa undangan kembali untuk memuji Tuhan, harapan agar Tuhan tetap dipuji, berkat, dan lain-lain. ${ }^{81}$

Jadi kalau digabungkan ketiga pendapat di atas, maka secara umum Mazmur Pujian dapat mempunyai struktur yang mempunyai beberapa bagian utama, seperti:

\section{Seruan kepada Yahweh: ${ }^{82}$}

“Ya TUHAN, Tuhan kami...” Mazmur 8:2

\section{Ajakan Untuk Menyembah atau Memuji Tuhan:}

Haleluya

Pujilah, hai hamba-hamba TUHAN)

Pujilah nama TUHAN (Mazmur 113:1)

Adalah baik untuk menyanyikan syukur kepada TUHAN

dan untuk menyanyikan mazmur bagi nama-Mu, ya Yang Mahatinggi (Mazmur 92:2). ${ }^{83}$

\section{Alasan Untuk Memuji atau Menyembah Tuhan.}

Setelah ajakan untuk memuji atau menyembah Tuhan, Mazmur Pujian biasanya dilanjutkan dengan uraian alasan mengapa Tuhan patut

\footnotetext{
80 Longman III, Bagaimana Menganalisa Kitab Mazmur?, h.15.

81 Barth dan Pareira, Kitab Mazmur 1-72, h.53.

82 Gerstenberger mengungkapkan bahwa bagian ini yang sering dihilangkan dalam Mazmur Pujian. Gerstenberger, Psalms Part 1, p.17.

83 Longman III, Bagaimana Menganalisa Kitab Mazmur?, h.16.
} 
dipuji dan biasanya didahului oleh kata depan כִ כִ (sebab, karena), ${ }^{84}$ contohnya:

Sebab TUHAN itu baik, kasih setia-Nya untuk selama-lamanya, dan kesetiaan-Nya tetap turun-temurun. (Mazmur 100:6)

Longman III dan Gunkel mengungkapkan bahwa bagian alasan memuji Tuhan ini merupakan bagian yang terpenting dari Mazmur ini. ${ }^{85}$ Alasan yang diungkapkan bukanlah sesuatu yang abstrak, tetapi sesuatu yang nyata, oleh karena Allah telah berbuat sesuatu dalam kehidupan pribadi atau umat Allah. ${ }^{86}$ Karya Tuhan yang sering kali dijadikan alasan memuji Tuhan adalah karya penciptaan alam semesta dan pemulihan serta penyelamatan atas bangsa Israel. ${ }^{87}$

\section{Ajakan Lebih Lanjut Untuk Menyembah atau Memuji Tuhan}

Kadang-kadang Mazmur Pujian juga diakhiri dengan ajakan lebih lanjut untuk memuji Tuhan, ${ }^{88}$ contohnya:

19 Hai kaum Israel, pujilah TUHAN!

Hai kaum Harun, pujilah TUHAN!

20 Hai kaum Lewi, pujilah TUHAN!

Hai orang-orang yang takut akan TUHAN, pujilah TUHAN!

21 Terpujilah TUHAN dari Sion,

Dia yang diam di Yerusalem!

Haleluya! (Mazmur 135:19-21)

Sedangkan yang berupa Berkat atau Harapan, contohnya: ${ }^{89}$

" TUHAN kiranya memberikan kekuatan kepada umat-Nya,

TUHAN kiranya memberkati umat-Nya dengan sejahtera!" Mazmur 29:11;

Aku hendak menyanyi bagi TUHAN selama aku hidup,

\footnotetext{
Longman III, Bagaimana Menganalisa Kitab Mazmur?, h.16-17.

Ibid., h.16. Gunkel, The Psalms, p.12.

Longman III, Bagaimana Menganalisa Kitab Mazmur?, h.16.

Ibid., h.17-18.

Longman III, Bagaimana Menganalisa Kitab Mazmur?, h.15.

89 Gerstenberger menyatakan bahwa bagian ini mempunyai peran kecil dalam Mazmur

Pujian. Gerstenberger, Psalms Part 1, p.17-18.
} 
aku hendak bermazmur bagi Allahku selagi aku ada.

Biarlah renunganku manis kedengaran kepada-Nya!

Aku hendak bersuka cita karena TUHAN.

Biarlah habis orang-orang berdosa dari bumi, dan

biarlah orang-orang fasik tidak ada lagi!

Pujilah TUHAN, hai jiwaku! Haleluya! Mazmur. 104:33-35

Claus Westermann mendefinisikan memuji (to praise) sebagai mengatakan, menceritakan, memberitakan dan membesarkan kemuliaan Allah. ${ }^{90}$ Westermann mengungkapkan bahwa pujian ini tidak dapat digantikan dengan korban, karena pujian ini mempunyai makna yang penting sebagaimana korban. ${ }^{91}$ Ia menyatakan: "Sacrifice is food for the god; praise, however, belongs to the life of the god as much as does food. ",92

Mazmur-mazmur yang termasuk Mazmur Pujian di antaranya: Mazmur 8, 19, 29, 33, 65, 66, 100, 103, 104, 111, 114, 135, 135, 136, $145-150 .^{93}$

\section{MAZMUR RATAPAN ATAU KELUHAN (LAMENT OR COMPLAINT PSALMS)}

Bruce K. Waltke berpendapat bahwa lebih sepertiga dari kitab Mazmur merupakan Mazmur Ratapan atau Keluhan yang mana terdiri 42 Mazmur Keluhan Pribadi dan 16 Mazmur Keluhan Komunal. ${ }^{94}$ Hal ini menunjukkan bahwa Mazmur Ratapan mempunyai tempat yang penting bagi kehidupan iman bangsa Israel. ${ }^{95}$

Tremper Longman III mengungkapkan bahwa spektrum emosi Mazmur Ratapan ini sangat bertentangan Mazmur Pujian, karena

\footnotetext{
90 Claus Westermann, Praise and Lament in the Psalms (Atlanta: John Knox Press, 1981), p.77.

91 Ibid.

92 Ibid.

93 Barth dan Pareira, Kitab Mazmur 1-72

94 Bruce K. Waltke, James M. Houston and Erika Moore, The Psalms as Christian Lament. A Historical Commentary. (Grand Rapids: Wm. B. Eerdmans Publishing Company, 2014), p.1.

95 Waltke, Houston and Moore, The Psalms as Christian Lament, p.1.
} 
berisikan tangisan dalam kesedihan yang hanya dapat pemazmur ungkapan kepada Allah. ${ }^{96}$ Mazmur Ratapan ini dapat dikenali dengan "mood", seperti kesedihan, tangisan, teriakan minta tolong ataupun tidak bersalah, dsb. Oleh karena "mood" semacam inilah Mazmur Ratapan tidak terlalu populer digunakan di kalangan kekristenan.

Patrick D. Miller Jr. mengungkapkan bahwa walaupun ada ajakan untuk mencurahkan isi hati yang penuh dengan tekanan oleh karena persoalan dalam ibadah, namun hal seperti itu jarang nampak dalam realita ibadah, sehingga Mazmur Ratapan belum mendapat tempat utama dalam ibadah komunal apalagi jika dibandingkan dengan Mazmur Pujian. $^{97}$

Bernd Janowski mengungkapkan bahwa secara umum " budaya ratapan " telah berkurang dalam kehidupan gerejani masa kini. ${ }^{98}$ Brian L. Webster dan David. R. Beach mengungkapkan bahwa kurangnya penggunaan ratapan disebabkan oleh pelbagai faktor, seperti pengaruh budaya, gaya hubungan, perspektif teologis dan pemahaman yang keliru tentang ratapan. ${ }^{99}$ Padahal ratapan itu merupakan sarana respons dari keterlukaan, kehilangan, ketidakadilan, dan kekuatiran. ${ }^{100}$

Janowski menyatakan bahwa penyebab hal ini oleh karena adanya pemahaman bahwa meratap adalah suatu sikap "mengasihani diri" ataupun sesuatu yang dapat menjadi "hujatan" kepada Allah. ${ }^{101}$

\footnotetext{
96 Longman III, Bagaimana Menganalisa Kitab Mazmur?, h.18.

97 Patrick D. Miller Jr., "Prayer and Worship," Calvin Theological Journal, 36 (2001), p.53.

98 Bernd Janowski, Arguing With God. A Theological Anthropology of the Psalms (Louisville: Westminster John Knox Press, 2013), p.36.

99 Budaya yang menekankan bahwa " lelaki tidak menangis" tidak memberi tempat bagi ratapan. Hubungan yang penuh kekerasan secara aktif ataupun pasif yang dialami anak-anak, akan membuat seseorang anak sulit untuk mengungkapkan perasaannya. Penggunaan Roma 8:28 atau Yosua 1:5 yang menitikberatkan berlebihan konsep kebaikan dan penyertaan Allah dalam segala peristiwa " menutup " kesempatan untuk mengungkapkan ratapan. Band. Brian L. Webster and David. R. Beach, "The Place of Lament in the Christian Life," Bibliotheca Sacra 164 (October-December 2007), 38996.

100 Webster and Beach, "The Place of Lament in the Christian Life," p.387.

101 Janowski, Arguing With God, p.38.
} 


\section{Mengalami Allah Melalui Kitab Mazmur}

Selanjutnya Janoskwi mengungkapkan bahwa ketidakmampuan untuk meratap sebenarnya merupakan akibat dari ketidakmampuan untuk menjadikan Allah sebagai satu-satunya perlindungan keselamatan dan keamanan. ${ }^{102}$

Walter Brueggemann mengutip pandangan Gerstenberger tentang Mazmur Ratapan ini tidak hanya berbicara tentang ekspresi iman Israel, tetapi juga berkaitan dengan bagaimana menjadi manusia. ${ }^{103}$ Gerstenberger mengungkapkan bahwa ratapan atau keluhan bukanlah suatu tindakan tidak beriman, tetapi justru merupakan iman yang mendalam. ${ }^{104}$

Mazmur Ratapan ini dapat dibagi menjadi Mazmur Ratapan Individu dan Mazmur Ratapan Komunal, yang mana dapat dikenali dengan penggunaan kata ganti orang tunggal atau jamak. ${ }^{105}$

\section{STRUKTUR ATAU GARIS BESAR}

Claus Westermann mengungkapkan struktur Mazmur Ratapan Komunal $^{106}$ adalah:

1. Alamat

2. Permohonan Awal

3. Ratapan

4. Pengakuan Keyakinan

5. Permohonan atau (Harapan Ganda)

6. Janji Untuk Memuji ${ }^{107}$

\footnotetext{
102 Janowski, Arguing With God, p.39.

103 Walter Brueggemann, "The Friday Voice of Faith," Calvin Theological Journal, 36 (2001), p14.

104 Ibid.

105 Longman III, Bagaimana Menganalisa Kitab Mazmur?, h.23.

106 Westermann mengunakan istilah "The Psalm of Petition or Lament of the the People". Claus Westermann, Praise and Lament in the Psalms, p.52.

107 Westermann, Praise and Lament in the Psalms, p.52.
} 
Sedangkan struktur Mazmur Ratapan Pribadi adalah:

1. Alamat dengan teriakan minta tolong awal

2. Ratapan

3. Pengakuan Keyakinan

4. Permohonan dan Alasannya

5. Keyakinan Didengar

6. Harapan Ganda

7. Janji Untuk Memuji

8. Pujian bagi Allah (hanya ketika permohonannya telah dijawab). ${ }^{108}$

Tremper Longman III mengungkapkan lebih sederhana dan umum Mazmur Ratapan dapat mempunyai beberapa bagian, seperti:

1. Doa dan Permohonan

2. Keluhan-keluhan

3. Pengakuan dosa atau pernyataan tidak bersalah

4. Kutukan pada musuh-musuh

5. Keyakinan pada respons Tuhan

6. Pujian atau berkat. ${ }^{109}$

\section{Doa dan Permohonan}

Tolonglah kiranya, TUHAN, sebab orang saleh telah habis, telah lenyap orang-orang yang setia dari antara anak-anak manusia.(Mazmur 12:2)

Dengarkanlah, TUHAN, perkara yang benar, perhatikanlah seruanku;

berilah telinga akan doaku, dari bibir yang tidak menipu.(Mazmur $17: 1)^{110}$

108 Westermann, Praise and Lament in the Psalms, p.64.

109 Longman III memisahkan antara doa dan permohonan minta tolong kepada Tuhan.

Band. Longman III, Bagaimana Menganalisa Kitab Mazmur?, h.20.

110 Huruf miring merupakan tambahan penulis. Band. Longman III, Bagaimana Menganalisa Kitab Mazmur?, h.20. 


\section{Keluhan-keluhan}

Janowski mengungkapkan adanya 3 aspek berkaitan dengan ratapan, yaitu:

1. Ratapan yang ditujukan kepada otoritas, seperti kepada Allah (accusation/tuduhan)

Allahku, Allahku, mengapa Engkau meninggalkan aku?

Aku berseru, tetapi Engkau tetap jauh dan tidak menolong aku. (Mazmur 22:2)

2. Ratapan yang ditujukan kepada diri sendiri (complaint/keluhan)

Seperti air aku tercurah, dan segala tulangku terlepas dari sendinya; hatiku menjadi seperti lilin, hancur luluh di dalam dadaku; kekuatanku kering seperti beling, lidahku melekat pada langitlangit mulutku;

dan dalam debu maut Kauletakkan aku.(Mazmur 22:15-16)

3. Ratapan yang ditujukan kepada musuh (lawsuit/dakwaan).

Sebab, lihat orang fasik melentur busurnya, mereka memasang anak panahnya pada tali busur, untuk memanah orang yang tulus hati di tempat gelap. Apabila dasar-dasar dihancurkan, apakah yang dapat dibuat oleh orang benar itu? (Mazmur 11:2-3) ${ }^{111}$

\section{Pengakuan Dosa atau Pernyataan Tidak Bersalah}

Ya Allah, Engkau mengetahui kebodohanku, kesalahan-kesalahanku tidak tersembunyi bagi-Mu. (Mazmur 69:9)

111 Janowski, Arguing With God, p.37-38. 
Sebab mataku tertuju pada kasih setia-Mu, dan aku hidup dalam kebenaran-Mu.

Aku tidak duduk dengan penipu, dan dengan orang munafik aku tidak bergaul;

aku benci kepada perkumpulan orang yang berbuat jahat, dan dengan orang fasik aku tidak duduk.

(Mazmur 26:3-5) $)^{112}$

\section{Kutukan kepada Musuh-musuh ${ }^{113}$}

Biarlah umurnya berkurang, biarlah jabatannya diambil orang lain.

Biarlah anak-anaknya menjadi yatim, dan istrinya menjadi janda. (Mazmur 109:8-9) ${ }^{114}$

\section{Keyakinan kepada Respons Allah}

Tetapi aku, kepada kasih setia-Mu aku percaya, hatiku bersorak-sorak karena penyelamatan-Mu. (Mazmur 13:6a)

\section{Pujian atau Berkat}

Aku mau menyanyi untuk TUHAN, karena Ia telah berbuat baik kepadaku. (Mazmur 13:6b)

Janowski menyatakan bahwa dalam Mazmur Ratapan selalu terdapat suatu pergerakan dari ratapan menuju kepada permohonan ataupun pujian. ${ }^{115}$ Tidak ada Mazmur Ratapan yang tetap berada dalam

112 Longman III, Bagaimana Menganalisa Kitab Mazmur?, h.22.

113 Biasanya kalau unsur kutukan kepada musuh-musuh ini sangat banyak atau mendominasi dalam suatu Mazmur, para ahli mengategorikannya sebagai Mazmur Kutukan, seperti Mazmur 58,59,69,79,83,109, dan 137.

114 Longman III, Bagaimana Menganalisa Kitab Mazmur?, h.21.

115 Janowski, Arguing With God, p.45. 


\section{Mengalami Allah Melalui Kitab Mazmur}

tahap ratapan saja. ${ }^{116}$ Claus Westermann juga mengungkapkan hal yang senada dan mengungkapkan bahwa tidak ada Mazmur yang tidak bergerak maju melampaui permohonan dan ratapan. ${ }^{117}$ Oleh karena selalu ada suatu pergerakan dari ratapan menuju kepada permohonan atau pujian dalam Mazmur Ratapan, maka sangatlah tepat jika Janowski berpendapat bahwa unsur ratapan dalam Mazmur ini bukanlah sekedar penggambaran penderitaan diri atau rasa kasihan diri yang akan menyebabkan berakhirnya penderitaan itu, tetapi ratapan ini berfungsi sebagai suatu permohonan kepada suatu pribadi yang dapat mengakhir penderitaan itu. ${ }^{118}$

Hal yang sama juga diungkapkan oleh Craig C. Boyles yang mengungkapkan bahwa Mazmur Ratapan itu bukanlah sekedar suatu ratapan yang hanya menangisi kesukaran yang dialami, tetapi tujuan ratapan itu adalah mendapatkan sesuatu dari Yahweh. ${ }^{119}$ Oleh karena itu penafsiran Mazmur Ratapan harus berkaitan bagaimana mazmur-mazmur ini mewujudkan suatu permohonannya. ${ }^{120}$ Mazmur Ratapan berbeda dengan ungkapan-ungkapan omelan dan gerutuan, tetapi merupakan ungkapan permohonan kepada Allah dan merupakan bagian untuk datang mendekat kepada Allah. ${ }^{121}$

Pemahaman ini sangat penting bagi pembaca masa kini dalam memahami ataupun menggunakan Mazmur-mazmur Ratapan. Mazmurmazmur ini memang memberi tempat untuk seseorang ataupun komunitas mengeluh dan meratap atas segala kesulitan, persoalan, ketidakadilan dan penderitaan yang ia atau mereka alami. Tahapan ini merupakan tahap manusiawi yang harus diberikan " wadah " bagi seseorang atau komunitas untuk mengeluh dan meratap atas pelbagai kesulitan dan penderitaan yang dialami, tetapi tahap ratapan atau keluhan ini bukanlah

\footnotetext{
116 Bahkan Mazmur 88 yang disebut "The Death Psalm” diakhiri dengan suatu permohonan kepada Tuhan (ayt. 11-13). Janowski, Arguing With God, p.45.

117 Claus Westermann, Praise and Lament in the Psalms (Atlanta: John Knox Press, 1981), p.74-75.

118 Janowski, Arguing With God, p.45.

119 Craig C. Boyles, The Conflict of Faith and Experience in the Psalms. A Form-Critical and Theological Study (Sheffield: JSOT Press, 1989), p.14.

120 Boyles, The Conflict of Faith and Experience in the Psalms, p.14.

121 Webster and Beach, "The Place of Lament in the Christian Life," p.395.
} 
semata-mata ungkapan mengasihani diri atau " berputar-putar" meratapi apa yang dialaminya, tetapi harus merupakan suatu bagian dari permohonan kepada Allah agar mau bertindak untuk menolong mereka dan semua keluhan atau ratapan itu harus bergerak ke arah pujian dan keyakinan kepada Allah.

Mazmur-mazmur yang termasuk Mazmur Keluhan Pribadi, di antaranya: Mazmur 5, 6, 7, 13, 17, 22, 26, 28, 31, 35, 38, 39, 41, 42-43, $51,55,56,57,61,63,64,69,70,71,86,88,102,109,120,130,140-$ 143. ${ }^{122}$ Sedangkan yang termasuk Mazmur Keluhan Komunal, di antaranya: Mazmur 12, 44, 58, 60, 74, 79. 80, 83, 85, 94, 123, $137 .{ }^{123}$

\section{MAZMUR UCAPAN SYUKUR}

Mazmur Ucapan Syukur adalah Mazmur yang berisikan suatu respon ucapan syukur dari keluhan pemazmur yang dijawab oleh Tuhan atau jawaban doa dari Tuhan. ${ }^{124}$ Mazmur Ucapan Syukur adalah pujian kepada Allah karena Ia telah menjawab doa. ${ }^{125}$

Claus Westermann mengungkapkan bahwa batas antara Mazmur Ucapan Syukur dan Mazmur Pujian sangat "cair". ${ }^{126}$ Westermann menyebut Mazmur Ucapan Syukur sebagai "the declarative Psalm of praise" dan Mazmur Pujian sebagai "the descriptive Psalm of praise". ${ }^{127}$ Westermann mengungkapkan bahwa Mazmur Ucapan Syukur merupakan ungkapan sukacita atas karya Allah yang baru saja kerjakan kepada pemazmur atau seorang yang sedang menaikkan ucapan syukur, sedangkan Mazmur Pujian merupakan pujian atas karya agung dan karakter mulia dari Allah secara umum. ${ }^{128}$

\footnotetext{
122 Barth dan Pareira, Kitab Mazmur 1-72, h.59.

123 Ibid.

124 Longman III, Bagaimana Menganalisa Kitab Mazmur?, h.24.

125 Ibid.

126 Claus Westermann, Praise and Lament in the Psalms, p.17.

127 Ibid., p.22.

128 Westermann, Praise and Lament in the Psalms, p.18, 31.
} 
Mazmur Ucapan Syukur biasanya dimulai sama dengan sebuah Mazmur Pujian. ${ }^{129}$ Pemazmur mengungkapkan keinginannya untuk memuji Tuhan:

Aku akan memuji Engkau, ya TUHAN, (Mazmur 30:2). ${ }^{130}$

Ada yang menyatakan sikap batin pemazmur:

Aku mengasihi TUHAN, (Mazmur 116:1) $)^{131}$

Atau ungkapan tentang indahnya bersyukur kepada Tuhan:

Adalah baik untuk menyanyikan syukur kepada TUHAN, dan untuk menyanyikan mazmur bagi nama-Mu, ya Yang

Mahatinggi, untuk memberitakan kasih setia-Mu di waktu pagi dan kesetiaan-Mu di waktu malam, dengan bunyi-bunyian sepuluh tali dan dengan gambus, dengan iringan kecapi. (Mazmur 92:2-4). ${ }^{132}$

Ada juga berupa ungkapan berkat:

Berbahagialah orang yang diampuni pelanggarannya, yang dosanya ditutupi! (Mazmur 32:1). ${ }^{133}$

Selanjutnya unsur penting atau inti yang terdapat dalam Mazmur Ucapan Syukur adalah motif (alasan) ucapan syukur yang mengungkapkan karya pertolongan Tuhan:

Aku akan memuji Engkau, ya TUHAN, sebab Engkau telah menarik aku ke atas, dan tidak memberi musuh-musuhku bersuka cita atas aku.

\footnotetext{
129 Longman III, Bagaimana Menganalisa Kitab Mazmur?,h.24.

130 Barth dan Pareira, Kitab Mazmur 1-72, h.65.

131 Ibid.

132 Ibid.

133 Longman III, Bagaimana Menganalisa Kitab Mazmur?,h.24.
} 
TUHAN, Allahku, kepada-Mu aku berteriak minta tolong, dan

Engkau telah menyembuhkan aku.

TUHAN, Engkau mengangkat aku dari dunia orang mati,

Engkau menghidupkan aku di antara mereka yang turun ke liang kubur. (Mazmur 30:2-4). ${ }^{134}$

Setelah mengucap syukur kepada Tuhan oleh karena Tuhan sudah menjawab doanya, pemazmur menyaksikan perbuatan Tuhan yang besar dalam hidupnya serta kemudian mengajak seluruh jemaat untuk juga mengucap syukur kepada Tuhan:

Nyanyikanlah mazmur bagi TUHAN, hai orang-orang yang dikasihi-Nya, dan persembahkanlah syukur kepada nama-Nya yang kudus! (Mazmur 30:5). ${ }^{135}$

Jadi Mazmur Ucapan Syukur itu secara sederhana mempunyai struktur:

1. Ajakan Untuk Bersyukur atau Memuji Tuhan

2. Alasan

3. Ajakan Untuk Bersyukur atau Memuji Tuhan

Sebagaimana yang diungkapkan oleh Westermann bahwa batas antara Mazmur Ucapan Syukur dan Mazmur Pujian sangat " cair ", ${ }^{136}$ sehingga kadang ada kesulitan untuk menentukan suatu Mazmur itu sebagai Mazmur Pujian atau Mazmur Ucapan Syukur. Hal yang dapat menolong dalam hal ini juga merupakan pendapat Westermann yang menyatakan bahwa Mazmur Ucapan Syukur merupakan ungkapan sukacita atas karya Allah yang baru saja kerjakan kepada pemazmur atau seorang yang sedang menaikkan ucapan syukur, sedangkan Mazmur Pujian merupakan pujian atas karya agung dan karakter mulia dari Allah secara umum. ${ }^{137}$

\footnotetext{
134 Barth dan Pareira, Kitab Mazmur 1-72, h.65.

135 Longman III, Bagaimana Menganalisa Kitab Mazmur?, p.25.

136 Claus Westermann, Praise and Lament in the Psalms, p.17.

137 Westermann, Praise and Lament in the Psalms, p.18,31.
} 
Mazmur Ucapan Syukur ini dapat merupakan ucapan syukur yang dinaikkan oleh perseorangan (Mazmur 30, 32, 92, 116, 138.) atau jemaah (Mazmur 67, 118, 124.) ${ }^{138}$

\section{MENGALAMI ALLAH MELALUI MAZMUR PUJIAN, MAZMUR KELUHAN DAN MAZMUR UCAPAN SYUKUR}

Melalui pengamatan sederhana, penulis menemukan bahwa orang Kristen memang cukup gemar membaca kitab Mazmur, tetapi kurang disertai dengan pemahaman yang lebih mendalam. Pemahaman pelbagai genre Mazmur akan memperkaya pembacaan, penelitian dan pemahaman kitab Mazmur yang semuanya itu akan membawa pengenalan dan pengalaman akan Allah yang lebih berarti dan mendalam.

NT Wright mengungkapkan bahwa dalam kekristenan masa kini kitab Mazmur tidak sungguh digunakan lagi, karena ayat-ayat tertentu dalam kitab ini dikutip hanya sekedar sebagai “ pengisi " bagian liturgi atau ibadah. ${ }^{139}$ Di tengah maraknya lagu penyembahan kontemporer, kitab Mazmur hanya dikutip di sana-sini, sehingga kekayaan kitab Mazmur ini belum tergali. ${ }^{140}$

Dalam kaitan dengan kurangnya penggunaan Mazmur Ratapan dalam ibadah Elisabeth Achtemeier mengungkapkan bahwa merupakan suatu kebohongan kalau suatu ibadah hanyalah berisi perayaan (celebration), karena ratapan merupakan suatu unsur ibadah yang penting dan merupakan suatu pengantar (prelude) pujian kepada Allah. ${ }^{141}$

Mazmur Ratapan atau Keluhan merupakan genre Mazmur yang sering kali tidak tergali dan tergunakan kekayaan rohaninya. Mazmur Pujian dan Mazmur Ucapan Syukur masih sering digunakan walau tidak

\footnotetext{
138 Barth dan Pareria, Kitab Mazmur 1-72, h.65.

139 NT Wright, The Case for the Psalms. Why They Are Essential (New York: Harper One, 2013), p.1.

140 Wright, The Case for the Psalms, p.5.

141 Elisabeth Achtemeier, "Preaching the Praises and Laments," Calvin Theological Journal, 36 (2001), p.105.
} 
digunakan dalam kepenuhan kekayaannya, oleh karena kurang disadarinya perbedaan dan kekhasan kedua genre Mazmur ini. ${ }^{142}$

Dalam upaya memaksimalkan kekayaan dari genre Mazmur Pujian, Mazmur Keluhan dan Mazmur Pujian dalam kehidupan dan ibadah orang percaya masa kini, penulis menggunakan skema OrientasiDisorientasi-Orientasi Baru dari Walter Brueggemann.

Dalam buku Spirituality of the Psalms, Walter Brueggemann mengungkapkan bahwa masa kehidupan manusia itu dapat dibuat skema Orientasi, Disorientasi dan Orientasi Baru. Orientasi adalah masa di mana manusia mengalami suatu keadaan yang baik dan penuh sukacita, Disorientasi adalah masa di mana manusia harus menghadapi luka, penderitaan, penderitaan, keterasingan, kebencian, dan lain-lain.; sedangkan Orientasi Baru adalah masa di mana manusia mengalami hadiah yang baru dari Allah memberikan sukacita ganti keputusasaan, terang ganti gelap, dan sebagainya. ${ }^{143}$ Dalam pelbagai masa kehidupan manusia itu mazmur mempunyai peran yang penting bagi kehidupan manusia. Dalam kaitan dengan hal ini Brueggemann menempatkan mazmur-mazmur yang ada dalam 3 tema utama, yaitu Mazmur Orientasi (psalms of orientation), Mazmur Disorientasi (psalms of disorientation) dan Mazmur Orientasi Baru (psalms of new orientation). ${ }^{144}$ Mazmurmazmur yang dikategorikan sebagai Mazmur Orientasi adalah Nyanyian Ciptaan (Mazmur. 8, 33, 104, dan 145), Nyanyian Taurat (Mazmur. 1, 15, 19, 24, dan 119), Mazmur Hikmat (Mazmur. 14, dan 37). ${ }^{145}$ Mazmurmazmur yang dikategorikan Mazmur Disorientasi adalah Nyanyian Keluhan Pribadi (Mazmur. 13, 35, dan 86), Nyanyian Keluhan Komunal (Mazmur. 74, 79, dan 137). ${ }^{146}$ Sedangkan mazmur-mazmur yang

\footnotetext{
142 Secara sederhana Mazmur Pujian adalah mazmur yang digunakan sebagai ungkapan pujian kepada Allah oleh karena seseorang atau komunitas mengingat karakter Allah dan karya Allah yang umum; sedangkan Mazmur Ucapan Syukur adalah mazmur yang digunakan untuk mengungkapkan ucapan syukur kepada Allah yang melakukan karya yang khusus kepada seseorang atau komunitas.

143 Walter Brueggemann, Spirituality of the Psalms (Minneapolis: Fortress Press, 2002), p.8-9.

144 Ibid., p.7-8.

145 Ibid., p.16-24.

146 Ibid., p.25-45.
} 
dikategorikan sebagai Mazmur Orientasi Baru adalah Nyanyian Ucapan Syukur Pribadi (Mazmur. 30, 34, 40 dan 138), Nyanyian Ucapan Syukur Komunal (Mazmur. 65, 66, 124, dan 129), Nyanyian Yahweh Sebagai Raja (Mazmur. 29, 47, 93, 97-99, dan 114), Nyanyian Pujian (Mazmur. $100,103,113,117,135$, dan 146-150). ${ }^{147}$

Skema Orientasi, Disorientasi dan Orientasi Baru ini dapat juga digunakan untuk membahas Mazmur Pujian (Orientasi), Mazmur Keluhan (Disorientasi) dan Mazmur Ucapan Syukur (Orientasi Baru). ${ }^{148}$ Ketika seseorang atau komunitas merenungkan karakter Allah (baik, setia, panjang sabar, murah hati, dan lain-lain) akan membawanya untuk memuji, mengagungkan dan membesarkan Allah. Ketika ia merenungkan karya penciptaan dan penyelamatan Allah, hatinya pasti dipenuhi dengan pujian dan penyembahan kepada Allah. Mazmur-mazmur Pujian dapat mewakili seseorang atau komunitas dalam tahap atau fase Orientasi ini. Hati yang penuh sukacita, kegembiraan dan pujian. Namun kehidupan umat Allah tidak hanya ditandai dengan sukacita, kegembiraan dan pujian, karena ada saat di mana kehidupan itu menjadi berat, membingungkan dan menekan. Dalam kondisi seperti ini tidak jarang sulit untuk dapat mengagungkan dan memuji Allah. Tahap atau fase ini oleh Brueggemann disebut sebagai Disorientasi. Dalam fase Disorientasi ini Mazmur-mazmur Keluhan menolong seseorang atau komunitas untuk mengeluarkan dan menyatakan gejolak batin dan emosi yang dialaminya melalui keluhan atau ratapannya kepada Allah. Keluhan atau ratapan ini tidak semata-mata gerutuan, ungkapan mengasihani diri sendiri ataupun hujatan, tetapi merupakan ungkapan yang jujur tentang keterlukaan, kesedihan, ataupun kebingungan kepada Allah dengan keyakinan bahwa Allah pasti akan memperhatikan dan menolongnya. Sebagaimana Mazmur Keluhan yang bergerak dari keluhan atau ratapan menuju kepada ungkapan kepercayaan atau pujian, seseorang atau komunitas diharapkan juga dalam bergerak dari keluhan atau ratapannya menuju kepada ungkapan kepercayaan atau pujian kepada Allah. Ketika keluhan atau

\footnotetext{
147 Brueggemann, Spirituality of the Psalms, p.46-57.

148 Penulis berbeda dalam menempatkan Mazmur Pujian dengan Walter Brueggemann. Penulis menempatkan Mazmur Pujian dalam tahap atau fase Orientasi, sedangkan Brueggemann menempatkannya dalam tahap atau fase Orientasi Baru.
} 
ratapannya telah didengar oleh Allah dan Allah menyatakan pertolonganNya yang khusus, seseorang atau komunitas dapat mengungkapkan ucapan syukurnya kepada Allah. Seseorang atau komunitas telah berpindah dari Disorientasi menuju ke Orientasi Baru. Dalam fase Orientasi Baru ini seseorang atau komunitas mengungkapkan ucapan syukur yang meluap dari hatinya oleh karena mengalami pertolongan Tuhan yang nyata. Mazmur-mazmur Ucapan Syukur dapat mewakili luapan ucapan syukur seseorang atau komunitas.

Mazmur-mazmur Pujian umumnya cukup sering digunakan dalam kehidupan orang percaya, khususnya dalam ibadah. Hal penting dalam penggunaan Mazmur-mazmur Pujian ini adalah penekanan pada aspek penyembahan dan pengagungan yang penuh dengan hormat di tengahtengah suasana sukacita dan sorak-sorai. Juga perlu diingatkan bahwa motif utama untuk memuji Allah adalah karakter Allah dan karya Allah yang umum (penciptaan, pembebasan, penyelamatan, dan lain-lain.). Praise and Worship dalam ibadah janganlah menjadi " doping " dan " pelarian emosi sesaat " bagi orang percaya di tengah-tengah beratnya kehidupan ini. Mazmur-mazmur Pujian dalam kitab Mazmur menolong orang percaya untuk menyembah dan mengagungkan Allah. Pujian dan penyembahan yang dimotivasi oleh kerinduan untuk menyembah dan mengagungkan Allah oleh karena karakter dan karya-Nya.

Memang harus diakui bahwa Mazmur-mazmur Keluhan sangat kurang digunakan dalam kehidupan dan ibadah orang percaya. Dalam konteks konseling Dominick D. Hankle memaparkan manfaat penggunaan Mazmur Kutukan ${ }^{149}$ sebagai cara yang tepat untuk pelepasan dan penyelesaian pelbagai emosi negatif, seperti kemarahan, kebencian dan frustrasi, ${ }^{150}$ namun Hankle tidak menggunakan bagian yang merupakan doa, ungkapan kepercayaan dan tekad untuk memuji Tuhan yang merupakan bagian penting dari Mazmur Keluhan (Mazmur Kutukan

149 Mazmur Kutukan dapat dikategorikan sebagai Mazmur Keluhan.

150 Dominick D. Hankle, "The Therapeutic Implications of the Imprecatory Psalms in the Christian Counseling Setting," Journal of Psychology and Theology, 2010, Vol. 38, N0. 4, p.275-280. 
merupakan bagian dari Mazmur Keluhan). Hankle hanya menggunakan Mazmur Kutukan ini sebatas sebagai pelepasan pelbagai emosi negatif.

Caroline Blyth menulis hal yang menarik tentang Mazmur 88 dalam konteks wanita Afrika penderita HIV-AIDS. ${ }^{151}$ Mazmur 88 adalah Mazmur Keluhan. Blyth mengungkapkan bahwa walaupun seseorang tidak mengetahui jenis penyakit yang diderita pemazmur, tetapi nampaknya ia menderita penyakit yang kronis (band. ayat 16 " Aku tertindas dan menjadi inceran maut sejak kecil, ..."152 Blyth menfokuskan pada ayat 9 dan 19 " Telah Kau jauhkan kenalan-kenalanku dari padaku, telah Kaubuat aku menjadi kekejian bagi mereka..." untuk menggambarkan keluhan penderita HIV-AIDS yang mengalami keterpisahan atau ketertolakan secara sosial. ${ }^{153}$ Tulisan Blyth hanya memfokuskan pada pergumulan pemazmur dan keluhannya yang dianalogikan dengan pergumulan dan keluhan penderita HIV-AIDS. Memang Mazmur 88 tidak mengungkapkan adanya ungkapan kepercayaan atau tekad untuk memuji Allah, namun Mazmur ini diawali dengan doa minta pertolongan kepada Allah ("Ya TUHAN, Allah yang menyelamatkan aku, siang hari aku berseru-seru, pada waktu malam aku menghadap Engkau. Biarlah doaku datang ke hadapan-Mu, sendengkanlah telinga-Mu kepada teriakku..." ayat 2 dan 3) serta di pertengahan terdapat doa dalam ayat 14 ("Tetapi aku ini, ya TUHAN, kepada-Mu aku berteriak minta tolong, dan pada waktu pagi doaku datang ke hadapan-Mu.") mengungkapkan pemazmur yang tetap berdoa dan minta tolong kepada Allah, sehingga Mazmur 88 ini tidak hanya sekedar ungkapan pergumulan dan keluh kesah, tetapi di tengah pergumulan yang sangat berat, ia tetap berdoa dan berharap bahwa Tuhan tetap akan menolongnya.

\footnotetext{
151 Caroline Blyth "I am Alone with My Sickness': Voicing the Experience of HIV-and AIDS- Related Stigma Through Psalm 88," Colloquium 44/2 2012, p.149-62.

Penderita HIV-AIDS ini merupakan wanita di benua Afrika yang ketularan oleh suaminya. Blyth juga menyebut beberapa Mazmur yang disebut Mazmur untuk orang sakit, seperti Mazmur. 6, 22, 38, 41, dan 102.

152 Blyth "I am Alone with My Sickness", p.150.

153 Ibid., p.153.
} 
Penggunaan Mazmur-mazmur Keluhan dalam ibadah sangatlah kurang. Oleh karena itu perlu suatu upaya yang serius untuk dapat menampilkan Mazmur-mazmur Keluhan ini, sehingga ibadah tidaklah sekedar ditandai dengan sukacita dan gembira, tetapi juga memberikan tempat bagi orang percaya yang datang beribadat dengan pelbagai beban berat dalam kehidupannya. Ibadah menjadi kaya dalam spektrum emosi. Sukacita dan dukacita, senang dan susah, penuh keyakinan dan keraguan, keteguhan dan kefrustasian, dan lain-lain. Memang Mazmur-mazmur Keluhan dapat merupakan pelepasan ungkapan pelbagai perasaan negatif (kemarahan, kekecewaan, frustrasi, dan lain-lain), tetapi harus dipahami hal ini sebagai tahapan yang harus berlanjut dalam doa, keyakinan akan pertolongan Allah dan tekad untuk memuji Allah. Hal ini akan membawa bahwa keluhan atau ratapan itu tidak sekedar ungkapan mengasihani diri atau bahkan hujatan kepada Allah, tetapi merupakan bagian dari ekspresi iman kepada Allah. Mazmur-mazmur Keluhan dalam kitab Mazmur mengajarkan umat percaya untuk tetap datang, berseru dan percaya kepada Allah di tengah beratnya pelbagai tekanan hidup. Umat dapat mengekspresikan kesedihan, keraguan, kekecewaan, kemarahan dan pelbagai emosi lainnya, namun semuanya itu tidak membawa mereka untuk menjauh dari Allah, tetapi justru mencari, meminta, dan mencari pertolongan hanya kepada Allah. Pengajaran dalam Mazmur-mazmur Keluhan membawa umat untuk makin mengalami Allah dalam pergumulan hidupnya.

Mengucap syukur merupakan salah wujud ekspresi iman orang percaya. Mengucap Syukur tidak boleh hanya menjadi suatu ritual oleh karena berkat-berkat yang dialami oleh umat tiap-tiap hari. Penyelidikan Mazmur-mazmur Ucapan Syukur memperkaya pemahaman tentang mengucap syukur. Ucapan Syukur lahir dari pengalaman nyata akan pertolongan Allah dalam kehidupan umat baik secara pribadi, maupun komunal. Ketika mereka mengalami kesulitan dan tantangan dalam kehidupan mereka (sakit, bahaya maut, bahaya musuh, bencana, dan lainlain), mereka berseru dan berteriak untuk minta pertolongan Allah. Ketika Allah menyatakan pertolongan dan penyelamatan atas mereka, hati mereka penuh ucapan syukur, sehingga lahirlah Mazmur-mazmur 
Ucapan Syukur. Ucapan-ucapan Syukur yang lahir oleh karena pengalaman-pengalaman yang dalam bersama dengan Allah.

Jadi Mazmur Pujian, Mazmur Keluhan atau Ratapan, dan Mazmur Ucapan Syukur menolong umat Allah dalam pelbagai spektrum kehidupannya. Dalam pelbagai spektrum kehidupan (OrientasiDisorientasi-Orientasi Baru) umat Allah dapat menggunakan mazmurmazmur ini dalam proses mengalami kehidupan bersama dengan Allah. Ketiga genre Mazmur ini mempunyai kekayaan masing-masing yang perlu diungkapkan dan digunakan dalam kehidupan umat percaya masa kini, sehingga umat Allah mempunyai pengalaman bersama dengan Allah secara benar (Alkitabiah), sehat (manusiawi) dan aktual (" new experiences ").

\section{DAFTAR PUSTAKA}

Barth, Marie Claire dan B.A. Pareira, Kitab Mazmur 1-72. Jakarta: BPK, 1997.

Boyles, Craig C., The Conflict of Faith and Experience in the Psalms. A Form-Critical and Theological Study. Sheffield: JSOT Press, 1989.

Brueggemann, Walter, Spirituality of the Psalms. Minneapolis: Fortress Press, 2002.

Froehlich, Karlfried, "Discerning the Voices: Praise and Lament in the Tradition of the Christian Psalter," Calvin Theological Journal, 36 (2001), p.75-90.

Gerstenberger, Erhard, Psalms Part 1 with an Introduction to Cultic Poetry. Grand Rapids: Wm. B. Eerdmans Publishing Company, 1991.

, Psalms, Part 2, and Lamentations. Grand Rapids: Wm. B. Eerdmans Publishing Company, 2001. 
Gunkel, Hermann, The Psalms. A Form-Critical Introduction. Philadelphia: Fortress Press, 1967.

Howard, Jr., David M., "The Psalms and Current Study," Interpreting the Psalms. Edited by Philip S. Johnston dan David G. Firth. Downers Grove: IVP Academic, 2005.

Janowski, Bernd, Arguing With God. A Theological Anthropology of the Psalms. Louisville: Westminster John Knox Press, 2013.

Johnston, Philip S., APPENDIX 1: INDEX OF FORM CRITICAL CATEGORIZATIONS," Interpreting the Psalms. Edited by Philip S. Johnston dan David G. Firth. Downers Grove: IVP Academic, 2005, 295-300.

Kraus, Hans-Joachim, Psalms 1-59. Minneapolis: Augsburg Publishing House, 1988.

Longman III, Tremper, Bagaimana Menganalisa Kitab Mazmur?. Malang: SAAT, 1994.

Peels, Eric, "Introduction," Psalms and Prayers. Papers Read at the Joint Meeting of the Society of Old Testament Study and Het Oudtestamentisch Werkgezelschap inNederland en België, Apeldoorn August 2006. Edited by Bob Becking and Eric Peels. Leiden: Brill, 2007.

Sweeney, M.A., "Form Criticism," Dictionary of the Old Testament. Wisdom, Poetry \& Writings (Downers Grove, IVP Academic, 2008.

Tucker, Jr., W.D., "Psalms 1: Book of," Dictionary of the Old Testament. Wisdom, Poetry \& Writings.Downers Grove, IVP Academic, 2008. van den End, Th., "Katekismus Besar Westminster," Enam Belas Dokumen Dasar Calvinisme. Jakarta: BPK, 2000. 
Waltke, Bruce K., James M. Houston and Erika Moore, The Psalms as Christian Lament. A Historical Commentary. Grand Rapids: Wm.

B. Eerdmans Publishing Company, 2014.

Westermann, Claus, Praise and Lament in the Psalms.Atlanta: John Knox Press, 1981.

Wilson, Gerald H., "The Structure of the Psalter," Interpreting the Psalms. Edited by Philip S. Johnston dan David G. Firth. Downers Grove: IVP Academic, 2005.

Wright, NT, The Case for the Psalms. Why They Are Essential. New York: Harper One, 2013.

\section{SUMBER JURNAL}

Achtemeier, Elisabeth, "Preaching the Praises and Laments," Calvin Theological Journal, 36 (2001), p.103-14.

Blyth, Caroline, "I am Alone with My Sickness': Voicing the Experience of HIV-and AIDS-Related Stigma Through Psalm 88," Colloquium 44/2 2012, p.149-62.

, “The Friday Voice of Faith," Calvin Theological Journal, 36 (2001), p.12-21.

Hankle, Dominick D., "The Therapeutic Implications of the Imprecatory Psalms in the Christian Counseling Setting," Journal of Psychology and Theology, 2010, Vol. 38, No. 4, p.275-80.

Miller Jr., Patrick D., "Prayer and Worship," Calvin Theological Journal, 36 (2001), p.53-62.

Sia, Kok Sin, "Analisa Bentuk Sebagai Salah Satu isi Kontemporer Dalam Penafsiran Perjanjian Lama," Jurnal Theologi Aletheia 1/2 (Maret 1996), h.103-16. 
Webster, Brian L. and David. R. Beach, "The Place of Lament in the Christian Life," Bibliotheca Sacra 164 (October-December 2007), p.387-402. 


\title{
"YESUS SEBAGAI PENGGENAP TEMPAT IBADAH" DALAM INJIL YOHANES
}

\author{
Stefanus Kristianto
}

\begin{abstract}
Abstrak: Salah satu karakteristik yang kerap muncul dalam Injil Yohanes ialah menampilkan Yesus sebagai penggenap ritual, figur, atau nubuatan dalam Perjanjian Lama. Bertolak dari dasar itu, tulisan ini akan mencoba berfokus pada bagaimana Injil Yohanes menampilkan Yesus sebagai penggenap tempat ibadah di dalam Perjanjian Lama. Untuk mencapai tujuan itu, penulis akan mulai dengan menunjukkan bahwa Perjanjian Lama merupakan latar belakang konseptual di balik Injil Yohanes. Setelah itu, penulis akan meneliti perkembangan konseptual tempat ibadah di dalam Perjanjian Lama untuk mengetahui aspek apa saja yang digenapi dan bagaimana Yesus menggenapinya. Pada akhirnya, penulis akan menarik beberapa implikasi praktis penggenapan tersebut bagi kehidupan Kristen kontemporer.
\end{abstract}

Kata Kunci: Yesus, Perjanjian Lama, Injil Yohanes, Penggenapan, Tempat Ibadah.

\begin{abstract}
One characteristic that frequently appears in the Gospel of John is to perform Jesus as the fulfilment of rites, figures, or prophecies in the Old Testament. Starting from that basis, this paper will try to focus on how the Gospel of John presents Jesus as the fulfilment of the place of worship in the Old Testament. To achieve that goal, the author will start by pointing out that the Old Testament is the conceptual background behind the Gospel of John. After that, the author will examine the conceptual development of the place of worship in the Old Testament, in order to find out what aspects are fulfilled and how Jesus fulfilled them. In the end, the author will draw some practical implications of that fulfilment for the contemporary Christian life.
\end{abstract}

Keywords: Jesus, the Old Testament, the Gospel of John , Fulfilment, Place of Worship 


\section{PENDAHULUAN}

Di dalam kehidupan beragama bangsa Israel, tempat ibadah tentu saja memainkan peran yang amat sentral. Bagi mereka, tempat ibadah merupakan lambang kehadiran Tuhan di tengah-tengah mereka. Di dalam tulisan ini, penulis akan mencoba menunjukkan wacana baru yang diungkapkan Injil Yohanes mengenai tempat ibadah, tepatnya bagaimana penulis Injil ini menampilkan Yesus sebagai penggenapan tempat ibadah di dalam Perjanjian Lama.

Dalam mencapai tujuan tersebut, pertama-tama penulis akan memaparkan latar belakang konseptual Injil Yohanes. Hal ini penting dilakukan untuk menunjukkan bahwa Yohanes memang sedang mengaitkan Yesus dengan Perjanjian Lama, dan bukan dengan konsep lainnya. Beberapa sarjana menganggap bahwa latar belakang konseptual Injil Yohanes adalah filsafat dualisme Yunani atau sejenisnya. Bila ini benar, maka argumen penulis bahwa Injil Yohanes menampilkan Yesus sebagai penggenap konsep tempat ibadah dalam Perjanjian Lama dengan sendirinya akan runtuh. Namun bila yang benar sebaliknya - bahwa latar belakang konseptual Injil Yohanes adalah tulisan Yahudi, termasuk juga Perjanjian Lama - maka tindakan penulis mengaitkan Injil Yohanes dengan Perjanjian Lama adalah tindakan yang valid. ${ }^{1}$

Penulis kemudian akan menguraikan sketsa perkembangan konsep tempat ibadah di dalam Perjanjian Lama untuk memperjelas aspek apa saja yang nanti akan digenapi oleh Yesus. Setelah itu, penulis akan menjelaskan bagaimana Yohanes menampilkan Yesus sebagai penggenap tempat ibadah di dalam Perjanjian Lama, sebelum akhirnya penulis akan menarik beberapa implikasi praktis penggenapan tersebut bagi kehidupan Kristen kontemporer.

\footnotetext{
Karena penulis membatasi diri hanya pada upaya Yohanes menampilkan Yesus sebagai penggenap tempat ibadah, maka pertanyaan krusial lain tidak akan dibahas di sini. Termasuk perkembangan konsep di dalam Yudaisme sendiri, yang setelah penghancuran Bait Allah pada tahun $70 \mathrm{M}$ oleh Titus Vespasianus, tidak lagi berupaya membangun Bait Allah, melainkan memilih untuk beribadah di sinagoga.
} 


\section{LATAR BELAKANG KONSEPTUAL INJIL YOHANES}

Pada awalnya, mayoritas sarjana Perjanjian Baru (mis. Bultmann, Haenchen, Dodd, Barret) cenderung melihat Injil Yohanes sebagai Injil yang sangat helenis. Berbagai usulan mereka nominasikan untuk menjadi latar belakang konseptual Injil ini, mulai dari Gnostisisme, Hermetica, filsafat Philo, Hellenistik Yahudi, dan berbagai wawasan dunia helenis lainnya. Konsep $\lambda o ́ \gamma o \varsigma$ dan dualisme (terang-gelap, atas-bawah, dan sebagainya) dianggap para sarjana tersebut sebagai rujukan eksplisit kepada filsafat Yunani. ${ }^{2}$

Akan tetapi, kini mayoritas sarjana lebih sepakat bahwa latar belakang konseptual Injil Yohanes ialah kultur dan tradisi religi Yahudi. Salah satu alasan mengapa para sarjana mulai meninggalkan anggapan bahwa Injil Yohanes dipengaruhi oleh filsafat Yunani ialah karena dangkalnya kesamaan yang diajukan antara Injil Yohanes dan tulisantulisan filsafat Yunani tersebut. Carson menyatakan,

"Words like light, darkness, life, death, spirit, word, love, believing, water, bread, clean, birth, children of God, can be found in almost any religion into which one probes. Frequently, they have diferent referents as one moves from religion to religion, but the vocabulary is as popular as religion itself.",

Di sini, Carson mengingatkan bahaya sikap yang disebut Samuel Sandmell sebagai "parallelomania," yakni mengemukakan paralelparalel yang arti pentingnya sebenarnya diragukan. ${ }^{5}$

\footnotetext{
Yakub Tri Handoko, Diktat Kuliah Injil Yohanes (Pacet: STTIAA, 2005), h.9.

D.A. Carson, The Gospel Accoding to John (PNTC; Grand Rapids: Eerdmans, 1991), p.59.

5 Samuel Sandmel, "Parallelomania," JBL 81 (1962): 2-13; untuk penjelasan singkatnya lihat D.A. Carson, Kesalahan-Kesalahan Eksegetis (trans. Lanna Wahyuni; Surabaya: Momentum, 2009), h.48-9.
}

4 Ibid. 
Penemuan Naskah Laut Mati juga menyadarkan para sarjana bahwa penggunaan bahasa dualistik dalam Injil Yohanes bisa berakar dalam tulisan Yahudi, dan tidak harus dikaitkan dengan filsafat Yunani. Itu sebabnya Carson mengatakan, "the 'new look' prompted by the discovery of the Dead Sea Scrolls has forced all but the most enthusiastic supporters of hellenistic influence to pause." Selain itu, pembacaan yang menyeluruh terhadap Injil Yohanes menunjukkan bahwa nosi Yohanes berpijak pada Perjanjian Lama sebagai stand-point sudah sangat konklusif. ${ }^{6}$ Sebab itu, kesimpulannya - seperti yang diungkapkan Carson - ialah,

"The fundamentally Jewish and Old Testament background to John's Gospel is increasingly recognized. What we call the Old Testament is what he repeatedly quotes, and that to which he repeatedly and explicitly alludes ... And the dominant influences, the things that constrain his thought and theology, are the Old Testament, the heritage of Judaism, his knowledge both of firstcentury Palestine and of the culture and heritage of those for whom he is writing, and above all his grasp of the person, ministry and work of Jesus the Messiah, and the Christian understanding that was mediated to him through the work of the Spirit in the life of the church.",

\section{SKETSA PERKEMBANGAN TEMPAT IBADAH DI DALAM PERJANJIAN LAMA}

Di dalam Perjanjian Lama, setidaknya ada tiga fase utama yang menandai perkembangan konsep tempat ibadah bangsa Israel, yakni fase pra-Mosaik yang merupakan fase paling sederhana, fase Mosaik sampai Davidik yang semi-permanen, dan fase Davidik hingga PaskaPembuangan yang jauh lebih stabil.

\footnotetext{
6 Untuk argumen-argumen yang mendukung nosi ini, lihat Handoko, Injil Yohanes, h.10-1.

7 Carson, John, pp. 59-60, 63.
} 


\section{Fase Pra-Mosaik}

Di dalam masa ini, terlihat jelas belum adanya sentralisasi tempat ibadah. Beberapa tokoh yang beribadah - baik dengan cara mendirikan mezbah dan/atau mempersembahkan korban ${ }^{8}$ - melakukannya di tempattempat yang sporadis. Tempat Kain dan Habel mempersembahkan korban di Kejadian 4 nampaknya tidak sama dengan tempat Nuh mempersembahkan korbannya di Kejadian 8, yang kemungkinan terjadi di sekitar gunung Ararat (8:4). Di dalam catatan kisah Abraham, bisa ditemukan bahwa ia beberapa kali mendirikan mezbah di tempat-tempat yang berbeda, misalnya di suatu tempat dekat Sikhem (Kejadian 12:6-7), di Betel dan Ai (Kejadian 12:8; 13:3-4), ${ }^{9}$ serta di gunung Moria ketika ia hendak mempersembahkan Ishak (Kejadian 22:9).

Ishak tercatat satu kali mendirikan mezbah bagi Tuhan di Bersyeba (Kejadian 26:25), sedangkan Yakub tercatat beberapa kali mempersembahkan korban maupun mendirikan mezbah, di antaranya satu kali mempersembahkan korban di pegunungan Gilead (Kejadian 31:54) serta dua kali mendirikan mezbah yaitu di Sikhem (Kejadian

8 Wenham menulis, "Sacrifice was the normal mode of worship in the OT ... Both building an altar and offering sacrifice were expressions of faith in the promise and were integral to the worship of God." [Gordon J. Wenham, Genesis 1-15 (WBC; Dallas: Word, 1987), 280].

9 Sailhamer mencatat bahwa bukan kebetulan tiga tempat ini (Sikhem, Betel, dan Ai) merupakan tempat yang sama yang dikunjungi Yakub ketika ia kembali ke Kanaan dari Haran (Kejadian 34-35), dan juga merupakan situs-situs yang diduduki dalam kisah penaklukan Kanaan di bawah Yosua. Mengutip Cassuto, Ia berpendapat bahwa alasan dari penyebutan ini ialah:

"... to show that what happened to Abraham also happened to Jacob and then also to their descendants. This is to show that the conquest of the land had already been accomplished in a symbolic way in the times of the fathers, demonstrated by means of their building their altars and purchasing property. Thus it shows that in the deeds of the fathers there is a source of trust that the Lord has cared for them from the very start and that he will still remain trustworthy in the days of the descendants of the fathers later on." [John Sailhamer, "Genesis," in Expositor's Bible Commentary 2 (Gen. Ed. Frank E. Gaebelain; Grand Rapids: Zondervan, 1990), 113].

Mengingat tujuan ini, nampaknya tidak salah untuk berpikir bahwa, meski tidak tercatat di dalam Alkitab, kemungkinan Abraham juga membangun mezbah di tempat-tempat lain. 
33:20) dan Betel (Kejadian 35:1, 3, 7, 14), serta sekali mempersembahkan korban di Bersyeba (Kejadian 46:1). Dari catatancatatan ini, bisa disimpulkan bahwa konsep tempat ibadah pada masa praMosaik masih sangat sederhana, dalam arti belum ada tempat ibadah yang terorganisir dan berpindah-pindah.

\section{Fase Mosaik sampai Davidik}

Pada masa Musa terjadi perkembangan signifikan dalam konsep tempat ibadah bangsa Israel. Meski pada awalnya bentuk ibadah masih meneruskan pola ibadah pra-Mosaik (band. Keluaran 17:15; 18:12), pada zaman Musa terjadi dua perkembangan besar dalam konsep tempat ibadah bangsa Israel. Perkembangan besar pertama ialah dimulainya model tempat ibadah yang semi-permanen. Bila pada masa pra-mosaik, tempat ibadah kebanyakan bersifat temporer, mayoritas membangun di tempat tertentu, dan setelah itu ditinggalkan, maka kini tempat ibadah umat Allah bersifat sedikit lebih permanen. Wujud perkembangan ini ialah dibangunnya Kemah Suci sebagai lokasi ibadah utama mereka. Tujuan pembangunan ini sendiri tercatat jelas dalam Keluaran 25:8, yakni “ supaya Aku akan diam di tengah-tengah mereka.” Dengan kata lain, Tabernakel sebagai tempat ibadah umat Allah yang semi-permanen, di saat yang sama juga menjadi lambang kehadiran Yahweh di tengahtengah bangsa Israel.

Bukan hanya soal aspek semi-permanen, perkembangan besar ini juga mencakup sentralitas tempat ibadah tersebut. Bila di masa pramosaik, umat Allah bebas beribadah dan mempersembahkan korban di mana saja, maka pada masa Musa muncul batasan agar mereka beribadah di satu tempat saja. Dekrit ini jelas diungkapkan Musa dalam Ulangan 12. Di sana, Musa mulai dengan mengingatkan bangsa Israel agar kelak ketika mereka memasuki tanah perjanjian, mereka harus memusnahkan semua mezbah dan tugu berhala serta tiang-tiang maupun patung-patung berhala penduduk setempat (ayat 3). Penggunaan bentuk piel dalam ayat ini nampaknya mengindikasikan bahwa umat Israel harus benar-benar menghilangkan segala bentuk penyembahan berhala tersebut. 
Setelah larangan itu, Musa dua kali menegaskan agar bangsa Israel beribadah hanya di tempat yang Tuhan pilih untuk menegakkan namaNya (ayat $5-7 ; 10-11$ ). Pengulangan ini nampaknya menunjukkan betapa pentingnya perintah ini untuk ditaati bangsa Israel. Tujuan perintah ini makin diperjelas di ayat 13-14, yakni supaya bangsa Israel tidak mempersembahkan korban di sembarang tempat yang mereka lihat melainkan hanya di tempat yang Tuhan pilih. ${ }^{10}$ Meskipun ada sedikit perkecualian di ayat 21 , namun secara umum aturan ini menjadi perintah mendasar bagi seluruh bangsa Israel.

Singkatnya, perkembangan besar kedua yang muncul dalam konsep tempat ibadah bangsa Israel ialah sentralisasi tempat ibadah, atau adanya satu tempat ibadah saja bagi bangsa Israel. Kedua aspek ini terus bertahan hingga nanti pada masa Daud terjadi penegasan.

\section{Fase Davidik sampai Paska-Pembuangan}

Pada masa Daud dan sesudahnya juga terjadi dua perkembangan dalam konsep bangsa Israel mengenai tempat ibadah mereka. Perkembangan pertama, tentu saja, ide tempat ibadah yang lebih permanen. Meskipun pembangunan tempat ibadah permanen baru terlaksana pada masa Salomo, tetapi ide awal pendirian tempat ibadah yang demikian dicetuskan oleh Daud (2 Samuel 7:1-3; 1 Tawarikh 17:12). Bahkan Daudlah yang mempersiapkan mayoritas material dan sumber daya manusia untuk pembangunan Bait Allah tersebut (1 Tawarikh 22:2 dan seterusnya; 28:1-29:9).

10 Terkait dengan ayat 13-14 ini, Craigie menulis:

"There was also a danger, warned against in these verses, that the people might be tempted to offer their legitimate burnt offerings to the Lord in illegitimate places; the words every place that you see refer by implication to Canaanite religious sanctuaries (see v. 2), though they could also refer to any place not sanctified by the Lord's choice. Hence $v .14$ repeats emphatically the note of $v .5$, that the sacrifices could be offered only in the place chosen by God."

Lihat Peter C. Craigie, The Book of Deuteronomyeronomy (NICOT; Grand Rapids: Eerdmans, 1976), p.218. Penekanan asli. 
Perkembangan kedua ialah penegasan terhadap signifikansi satu tempat ibadah. Sejak Salomo mendirikan Bait Allah, maka konsep satu tempat ibadah bagi bangsa Israel makin diperkuat, sebab hanya di Bait Sucilah tempat yang Allah kuduskan bagi nama-Nya (band. 1 Raja-Raja 9:7). Penegasan ini makin terlihat jelas dalam dua hal. Pertama, rujukan yang cenderung bernada negatif terhadap raja-raja yang tidak memusnahkan bukit-bukit pengorbanan, meskipun secara umum mereka memiliki karakter hidup yang baik. Misalnya Asa (1 Raja-Raja 15:14 ), Yosafat (1 Raja-Raja 22:44), Yoas (2 Raja-Raja 12:3), Amazia (2 RajaRaja 14:4), Azarya (2 Raja-Raja 15:3), dan Yotam (2 Raja-Raja 15:35).

Beberapa orang menganggap bukit-bukit pengorbanan tersebut merupakan bukit-bukit pengorbanan bagi berhala, sehingga rujukan negatif tersebut dimaksudkan untuk mencela toleransi raja-raja tersebut terhadap penyembahan berhala yang masih di terjadi di kalangan bangsa Israel; bukan soal sentralitas tempat ibadah. Akan tetapi, pandangan demikian nampaknya tidak terlalu tepat, khususnya karena rujukan di 1 Raja-Raja 3:2 yang mengaitkan keberadaan bukit-bukit pengorbanan tersebut dengan belum adanya Bait Allah. Ayat ini jelas mengindikasikan bahwa bukit-bukit pengorbanan tersebut dibuat untuk penyembahan kepada Allah, bukan untuk penyembahan kepada berhala. Jadi, masalah dengan bukit-bukit pengorbanan ialah karena keberadaannya mengingkari perintah yang disampaikan melalui Musa, bahwa hanya boleh ada satu tempat ibadah. ${ }^{11}$

11 Senada dengan itu, R. D. Patterson and Hermann J. Austel menulis:

"The high places were a constant sore point in Israel, and the prophets of God frequently spoke out against them. There were two basic problems with them: (1) they detracted from the principle of the central sanctuary (Deuteronomy 12:1-14); and (2) since worship at high places was a Canaanite custom, syncretism was not only a very real danger but an all too common occurrence. Israel was specifically forbidden to utilize pagan high places and altars (Deuteronomy 12:2-4, 13), and as soon as God had established his people in the Land of Promise, they were to worship at a sanctuary in the place appointed by God."

Lihat R. D. Patterson and Hermann J. Austel, “1 \& 2 Kings,” Expositor's Bible Commentary 4 (Gen.ed. Frank E. Gaebelein; Grand Rapids:Zondervan, 1988), p.43. Penekanan ditambahkan. 
Penegasan kedua ialah munculnya teologi doa dengan berpusat (1 Raja-Raja 8:31-43) dan berkiblat (1 Raja-Raja 8:44-45; 48-49) pada Bait Allah di dalam doa Salomo. Pada masa selanjutnya, aspek ini nampaknya mengakar lebih kuat dalam diri bangsa Yehuda. Misalnya, praktik doa kiblat yang dilakukan Daniel di dalam Daniel 6:11, jelas sangat dipengaruhi konsep bahwa hanya ada satu tempat ibadah yang benar, simbol kehadiran Allah yang sah, yakni di Yerusalem. Karena itulah, ia berdoa menghadap ke Yerusalem.

\section{Konklusi}

Dari pembahasan singkat di atas, terlihat bahwa konsep tempat ibadah di dalam Perjanjian Lama, mulai dengan bentuk yang masih sederhana, yakni sporadis dan tidak permanen, menuju ke bentuk yang semi permanen dan terpusat di masa Musa, hingga akhirnya mencapai bentuk yang permanen dan sangat terpusat di masa Daud dan sesudahnya. Satu aspek penting yang perlu diperhatikan di sini ialah sentralitas tempat ibadah tersebut. Hanya ada satu tempat ibadah di tempat yang Tuhan tentukan, tidak ada yang lain! Signifikansi ini terlihat jelas pada masa kemudian ketika Zerubabel dan Herodes membangun kembali Bait Allah di situs yang sama dengan tempat Salomo membangun Bait Allah pertama kali. Sementara catatan di Kisah Rasul 2 mengenai orang-orang Yahudi yang berkumpul di Yerusalem pada perayaan Pentakosta nampaknya mengindikasikan bahwa konsep sentralitas tempat ibadah ini bertahan, setidaknya, hingga masa hidup Tuhan Yesus dan para rasul.

\section{INJIL YOHANES: YESUS SEBAGAI PENGGENAP}

Setelah memahami bagaimana perkembangan konsep tempat ibadah di dalam Perjanjian Lama, penulis akan memaparkan bagaimana Injil Yohanes menampilkan Yesus sebagai penggenap tempat ibadah tersebut. Di dalam menunjukkan Yesus sebagai penggenap tempat ibadah Perjanjian Lama, ada empat teks kunci yang digunakan Yohanes di dalam Injilnya. 


\section{Yohanes 1:14}

Teks pertama ialah Yohanes 1:14, “Firman itu telah menjadi manusia, dan diam di antara kita, dan kita telah melihat kemuliaan-Nya, yaitu kemuliaan yang diberikan kepada-Nya sebagai Anak Tunggal Bapa, penuh kasih karunia dan kebenaran." Menarik dicatat bahwa kata " diam" atau " tinggal " yang digunakan Yohanes di sana bukan kata yang umum digunakan, yakni $\mu \epsilon \nu \omega$. Di sini Yohanes menggunakan kata kerja Ł́ $\sigma \kappa \eta ́ \nu \omega \sigma \epsilon \nu$ yang hanya muncul dua kali di dalam Alkitab, yakni ayat ini dan satu lagi di dalam Kitab Wahyu. Brown mencatat bahwa secara etimologis, kata ini terkait dengan kata $\sigma \kappa \eta \nu \eta$ (tenda) dan secara literal berarti "memasang sebuah tenda"" atau "bertabernakel."

Penggunaan kata ini jelas mengingatkan pembaca Injil Yohanes pada kemah peribadatan bangsa Israel di Perjanjian Lama. ${ }^{13}$ Ridderbos mengatakan bahwa motif dasar penggunaan kata kerja ini ialah tabernakel di padang belantara di mana kehadiran Allah di Israel dan kemuliaan-Nya dinyatakan. ${ }^{14}$ Morris menambahkan, “ That John wants us to recall God's presence in the tabernacle in the wilderness seems clear from the immediate reference to "glory," for glory was associated with the tabernacle."15 Melalui penggunaan kata ini, Yohanes ingin menunjukkan kepada pembacanya bahwa Yesus adalah anti-type dari type tabernakel di Perjanjian Lama: sebagaimana dahulu Allah menyatakan kemuliaan kehadiran-Nya melalui tabernakel, maka kini Allah menyatakan kemuliaan-Nya dengan cara yang lebih personal, yakni melalui AnakNya yang berkemah di tengah-tengah manusia.

Raymond E. Brown, The Gospel According to John I-XII (AB; New Haven: Yale, 2008), p.13.

13 Lihat Carson, John, p.127.

14 Herman Ridderbos, Injil Yohanes: Suatu Tafsiran Theologis (trans. Lanna Wahyuni; Surabaya: Momentum, 2012), h.55.

15 Leon Morris, The Gospel According to John (NICNT; Grand Rapids: Eerdmans, 1995), p.91. 


\section{Yohanes 1:51}

Teks kedua yang perlu disimak adalah Yohanes 1:51. Bagian ini termasuk dalam bagian percakapan Yesus dengan Natanel. Dalam bacaan ini dikisahkan bahwa Yesus menjawab keraguan Natanel di ayat 46 dengan menunjukkan pengetahuan supranatural-Nya (ayat 47-48). Kemudian meresponi kepercayaan Natanel, Yesus mengatakan bahwa murid-murid akan melihat hal-hal yang lebih besar (ayat 50). Salah satu wujudnya ialah: "....sesungguhnya engkau (kalian) akan melihat langit terbuka dan malaikat-malaikat Allah turun naik kepada Anak Manusia" (ayat 51). ${ }^{16}$

Jawaban yang Yesus berikan ini mengingatkan pembaca kepada peristiwa Yakub di Betel (Kejadian 28:10-22). Di sana, Yakub bermimpi melihat sebuah tangga yang ujungnya sampai di langit dan malaikat Allah naik turun $^{17}$ di tangga itu. Ungkapan "malaikat-malaikat Allah naik turun" jelas menjadi penanda yang menunjukkan bahwa Yesus memang sedang merujuk pada peristiwa Yakub di Betel tersebut. ${ }^{18}$

Meski demikian, ada dua perbedaan antara ucapan Yesus dan mimpi Yakub di Betel. Pertama, di dalam mimpi Yakub tidak ada catatan soal "langit terbuka," sebuah gambaran khas apokaliptik Yahudi, yang berbicara tentang penerimaan visi dari dunia yang berbeda. ${ }^{19}$ Penambahan ini nampaknya dipengaruhi oleh kemunculan gelar "Anak Manusia" di ayat ini. Kostenberger menulis bahwa gambaran apokaliptik tentang "langit terbuka" memang beberapa kali dikaitkan dengan sebutan "Anak Manusia." ${ }^{20}$ Kedua, di dalam mimpi Yakub, malaikat-malaikat

\footnotetext{
16 Carson dengan tepat menuliskan: "Although Jesus is adressing Nathanael, the "you" to whom he promises the vision of $v .51$ is plural; the vision is probably for all the disciples, and by extension, for those who would follow them." (Carson, John, p.163).

17 Terjemahan LAI "turun naik" tidak tepat, sebab kata "naik" diletakkan lebih dulu. Morris mengatakan, "In both the angels are saidn to ascend first, which may imply their presence on earth already." (Morris, John, p.149).

18 Morris menulis, "the ascent and descent of angels seems to be a reference to the vision of Jacob" (Ibid).

19 Kostenberger, John, p.85.

20 Ibid., p.86.
} 
tersebut naik turun di tangga, sementara di dalam ucapan Yesus, malaikat-malaikat tersebut naik turun menuju kepada Anak Manusia. ${ }^{21}$ Jadi, di sini, Yesus digambarkan menjadi penghubung antara surga dan bumi.

Lantas apa maksud Yohanes memasukkan bagian ini? Dengan menyertakan ucapan ini, Yohanes sedang menunjukkan bahwa Yesus adalah Betel (Rumah Allah) yang baru. ${ }^{22}$ Bila dahulu Allah menyatakan diri-Nya di Betel, maka kini Allah tidak lagi menyatakan diri-Nya di sana, melainkan di dalam Yesus. ${ }^{23}$ Yesuslah yang kini menjadi penghubung antara surga dan bumi, dan melalui Dialah hal-hal surgawi akan disingkapkan.

\section{Yohanes 2:19-21}

Teks ketiga yang perlu diperhatikan ialah Yohanes 2:19-21. Teks ini merupakan bagian dari episode penyucian yang dilakukan Yesus terhadap bait Allah. Ketika orang-orang Yahudi menantang otoritas Yesus dengan meminta tanda kepada-Nya (ayat 18), Ia menjawab, "Rombak Bait Allah ini, dan dalam tiga hari Aku akan mendirikannya kembali" (ayat 19). Yohanes kemudian menampilkan sebuah misunderstanding ${ }^{24}$ dari orang-orang Yahudi mengenai pernyataan Yesus tersebut ketika mereka berkata, "Empat puluh enam tahun orang mendirikan Bait Allah ini dan Engkau dapat membangunnya dalam tiga hari?" (ayat 20). Yohanes lantas memberikan komentar teologis bahwa sebenarnya yang dimaksudkan Yesus dengan Bait Allah ialah tubuh-Nya sendiri (ayat 21).

Para sarjana tidak sependapat mengenai kaitan kisah ini dengan catatan penyucian di Sinoptik yang terjadi di akhir pelayanan Yesus. Beberapa sarjana (mis. Blomberg, ${ }^{25}$ Carson, ${ }^{26}$ Morris $^{27}$ ) beranggapan

\footnotetext{
Ungkapan "Anak Manusia" di sini merupakan interlokutor untuk Yesus sendiri.

Kostenberger, John, p.86.

Carson, John, p.164.

Untuk memahami misunderstanding dalam Injil Yohanes, lihat D.A. Carson,

"Understanding Misunderstandings in the Fourth Gospel," TynB 33 (1982): p.59-91.

25 Craig L. Blomberg, The Historical Reliability of the Gospel ( $2^{\text {nd }}$ edition; Downers

Grove: IVP, 2007), p.216-9.
} 
bahwa Yesus menyucikan Bait Allah setidaknya sebanyak dua kali, yakni di awal pelayanan-Nya (sebagaimana dicatat Yohanes) dan di akhir pelayanan-Nya (sebagaimana dicatat Injil Sinoptik). Akan tetapi, menimbang beberapa hal nampaknya lebih tepat memaknai bahwa Yesus menyucikan bait Allah hanya sekali, yakni sesuai dengan catatan Sinoptik, menjelang akhir pelayanan-Nya. ${ }^{28}$ Pertama, ini sesuai dengan natur Yohanes yang lebih teologis ketimbang kronologis dibanding Injil Sinoptik. ${ }^{29}$ Kedua, meski memang ada kemungkinan Yesus melakukan atau mengajarkan suatu hal beberapa kali, sehingga menghasilkan catatan yang berbeda. Namun, tidak berarti bahwa semua catatan yang berbeda menunjukkan bahwa hal tersebut dilakukan Yesus beberapa kali. Catatan penyangkalan Petrus di dalam Injil Yohanes dan Injil Sinoptik juga tidak persis sama, namun tidak berarti bahwa Petrus menyangkal lebih dari tiga kali. Ketiga, tindakan Yesus menyucikan Bait Allah tentunya merupakan tindakan yang amat serius bagi pemimpin agama Yahudi. Jadi, nampaknya hampir mustahil bila mereka membiarkan peristiwa tersebut terjadi sampai dua kali.

Lantas mengapa Yohanes menempatkan kisah penyucian ini di awal pelayanan Yesus? Nampaknya, lagi-lagi Yohanes memiliki alasan teologis di baliknya. Yohanes kembali ingin menampilkan Yesus sebagai penggenap berbagai ritual keagamaan di dalam agama Yahudi. Setelah menampilkan Yesus sebagai penggenap tabernakel (1:14), ritual korban (1:29-34), dan ritual penyucian (2:1-11), kini Yohanes kembali menampilkan Yesus sebagai penggenap tempat ibadah: Yesus adalah Bait Allah sebenarnya. Melalui tipologi Bait Allah dan tubuh-Nya, Yohanes kembali ingin menegaskan bahwa Yesuslah lambang kemuliaan dan kehadiran Allah di tengah-tengah umat manusia, dan karenanya, patut menjadi pusat penyembahan. Atau, seperti yang dikatakan Carson,

\footnotetext{
Carson, John, p.177-8.

Morris, John, p.166.

Band. Brown, John I-XII, p.117.

29 Ini tidak berarti menyatakan bahwa Injil Yohanes tidak reliabel secara historis. Apa yang penulis maksud ialah bahwa Yohanes kerapkali menyusun peristiwa-peristiwa historis tersebut lebih tidak kronologis demi tujuan teologis yang Ia ingin sampaikan.
} 
"Therefore it is the human body of Jesus that uniquely manifests the Father, and becomes the focal point of the manifestation of God to man, the living abode of God on earth, the fulfilment of all the temple meant, and the centre of all true worship (over against all other claims of 'holy space', 4:20-24). In this 'temple' the ultimate sacrifice would take place; within three days of death and burial, Jesus Christ, the true temple, would rise from the dead. ${ }^{, 30}$

\section{Yohanes 4:20-24}

Ketiga teks penggenapan tadi berpuncak pada teks keempat yang ada dalam Yohanes 4:20-24. Setelah seorang perempuan Samaria berbincang dengan Yesus perihal kehidupan pribadinya, ia akhirnya mengakui bahwa Yesus ialah seorang nabi (ayat 19). Pengakuan tersebut nampaknya membuat perempuan tersebut tertarik membawa perdebatan besar antara bangsa Yahudi dan orang Samaria (perihal manakah tempat ibadah yang paling benar) ke dalam diskusinya dengan Yesus (ayat 20). Pada dasarnya kedua bangsa ini percaya bahwa Allah memerintahkan mereka untuk beribadah di tempat yang Ia tentukan (band. Ulangan 12:5). Namun, perbedaan tempat muncul karena orang-orang Samaria hanya menerima Taurat sebagai Kitab Suci mereka.

Karena orang Yahudi menerima keseluruhan Kanon Ibrani, maka mereka beranggapan bahwa Yerusalem ialah tempat yang Allah pilih untuk menegakkan nama-Nya. Daud memilih Yerusalem sebagai tempat didirikannya Bait Allah, dan Allah menyetujui niatnya itu ketika Ia menyertai pembangunan Bait Allah pada masa Salomo. Namun, orang Samaria tidak menerima keyakinan tersebut. Alih-alih menerima Yerusalem sebagai pusat ibadah, mereka justru mencari tempat suci lain di dalam Taurat. Mereka menemukan bahwa Sikhem, yang terlihat dari bawah Gunung Gerizim, adalah tempat pertama Abraham membangun mezbah ketika ia memasuki tanah perjanjian (Kejadian 12:6). Di Gunung

30 Carson, John, p.182. Penekanan ditambahkan. Band. juga kutipan Kostenberger terhadap Barret, "The human body of Jesus was the place where a unique manifestation of God took place and consequently became the only true Temple, the only centre of true worship." Lihat Andreas J. Kostenberger, John (BECNT; Grand Rapids: Baker, 2004), p.110. 
Gerizim pula berkat diucapkan (Ulangan 11:29-30; 27:2-7). Bahkan berdasarkan Kitab Suci mereka, orang Samaria memercayai bahwa Sepuluh Perintah Allah punya kaitan yang erat dengan Gunung Gerizim. ${ }^{31}$ Ini semua membuat mereka akhirnya memilih Gunung Gerizim sebagai tempat suci di mana mereka menyembah Allah.

Jawaban Yesus di ayat 21 mengindikasikan bahwa pertanyaan soal legalitas tempat ibadah tersebut bukanlah pertanyaan yang relevan bagiNya. Meskipun Ia mengakui superioritas bangsa Yahudi di ayat 22, tetapi pada akhirnya Yesus menjelaskan datangnya sebuah babak baru dalam konsep tempat ibadah Alkitabiah: nilai sebuah ibadah tidak lagi ditentukan dari " di mana seseorang menyembah" tetapi " bagaimana seseorang itu menyembah." Di ayat 23-24 Yesus berbicara bahwa penyembah yang benar menyembah Allah di dalam roh dan kebenaran.

Para sarjana memberikan beragam pendapat mengenai arti roh dan kebenaran dalam ucapan Yesus ini. Ridderbos misalnya berpendapat bahwa roh dan kebenaran menunjuk kepada persekutuan yang dibangun dalam kuasa-Nya yang menciptakan kehidupan dan memberi kehidupan, yang memimpin kepada kepenuhan karunia Allah (band. 1:16) yang tidak lagi diperantarai oleh segala macam kesementaraan dan simbolis, tetapi oleh Roh Allah sendiri. ${ }^{32}$ Sementara Morris menulis,

"It is not likely that "spirit" here means the Holy Spirit (though the Spirit does help our worship, Roma 8:26ff). It is the human spirit that is in mind. One must worship, not simply outwardly by being in the right place and taking up the right attitude, but in one's spirit ... The combination "spirit and truth" points to the need for complete sincerity and complete reality in our approach to God. There is an important point in the concluding statement that the Father seeks such to be his worshipers. "33

Carson, John, p.222.

Ridderbos, Injil Yohanes, h.175.

Morris, John, p. 239. 
Penjelasan yang lebih tepat konteks diberikan oleh Carson dan Kostenberger. ${ }^{34}$ Mereka berpendapat bahwa maksud Yesus dalam frasa " menyembah dalam roh dan kebenaran" ialah penyembahan yang tidak terikat pada tempat kudus tertentu - seperti halnya kehadiran Allah yang adalah roh, yang tidak terikat oleh tempat tertentu - dan berfokus pada Allah yang memperkenalkan diri-Nya secara penuh di dalam Anak-Nya, Sang Kebenaran (Yohanes 14:6). Jadi, ketika perempuan tersebut mempertanyakan di situs manakah sebuah penyembahan dianggap legal, Yesus menyatakan bahwa legalitas penyembahan tidak lagi didasarkan pada lokasi - sebab Allah yang roh itu tidak dikurung oleh lokasi - tetapi pada sikap hati yang berfokus pada Yesus, Sang Kebenaran.

\section{SIMPULAN DAN IMPLIKASI}

Yohanes menunjukkan dalam Injilnya bahwa konsep tempat ibadah bangsa Israel telah menemukan penggenapannya di dalam diri Yesus: Yesus adalah Sang Tabernakel sejati (Yohanes 1:14), Betel sejati (Yohanes 1:51), dan Bait Allah sejati (Yohanes 2:19-21). Melalui penggenapan ini, Yesus membawa babak baru dalam konsep ibadah alkitabiah. Nilai legalitas ibadah tidak lagi ditentukan berdasarkan tempat di mana seseorang menyembah seperti yang diyakini bangsa Israel dan dipertanyakan seorang perempuan Samaria dalam Yohanes 4. Allah adalah roh yang tidak dibatasi oleh tempat, oleh sebab itu penyembahan kepada-Nya juga seharusnya tidak dibatasi oleh batas-batas spasial, seolah tempat yang satu lebih kudus daripada tempat yang lain. Sebaliknya, nilai sebuah ibadah ditentukan dari bagaimana orang itu menyembah: apakah ia menyembah dengan berfokus pada Allah yang dikenal melalui Yesus atau tidak? Ibadah baru memiliki nilai ketika ibadah tersebut berfokus pada Yesus, Sang Kebenaran Allah.

Mengingat tujuan besar Injil Yohanes yang bersifat misional (band. Yohanes 20:30-31), bagi pembaca pertama Injil Yohanes, penggenapan ini nampaknya menjadi salah satu bagian dari upaya besar Yohanes mempersuasi orang-orang non-Kristen (khususnya Yahudi diaspora dan

34 Carson, John, p.224-6; Kostenberger, John, p.156. 
orang-orang non-Yahudi yang tertarik dengan Yudaisme) bahwa orangorang Kristenlah penerus ibadah yang sejati yang dimulai Allah sejak jaman Perjanjian Lama. Ini sama dengan apa yang diungkapkan Kostenberger, bahwa 'John's emphasis on Jesus' replacement of the temple and Jewish feast probably represent an effort to exploit the temple's destruction evangelistically in an effort to reach diaspora Jews and Gentiles attracted to Judasim." 35

Dari pembahasan ini, setidaknya ada empat implikasi yang bisa direnungkan bagi kekristenan kontemporer:

1. Karena menyembah dalam roh dan kebenaran berbicara tentang penyembahan yang tanpa batas dan berfokus pada Yesus, maka pandangan kelompok Pentakosta-Karismatik yang mengaitkan frasa ini sebagai dukungan bagi pola ibadah dengan berbahasa roh atau bentuk-bentuk " ekstase roh" lainnya jelas tidak mendapat dukungan dari teks ini.

2. Kegiatan kelompok Kristen tertentu yang mengadakan baptis ulang, pemberkatan nikah ulang ataupun ibadah khusus dalam ziarah iman di tanah Israel pada dasarnya bukan sikap yang alkitabiah. Sikap tersebut mengesankan seolah ritual di tanah Israel lebih bernilai dan diperkenan Tuhan ketimbang ritual ibadah di gereja lokal. Dengan kata lain, sikap demikian pada dasarnya menyangkali penggenapan Yesus terhadap konsep tempat ibadah Perjanjian Lama.

3. Perlukah tempat ibadah fisik? Tentu saja, sebab orang-orang Kristen sendiri masih terikat pada batas-batas ruang. Namun demikian, orang-orang Kristen perlu berhati-hati terhadap pengultusan tempat atau ruangan tertentu. Seolah ibadah di tempat tertentu lebih suci dan berkenan kepada Allah dibanding tempat lainnya. Sekali lagi, nilai ibadah yang sejati tidak lagi terletak pada "di mana" tetapi pada "bagaimana."

4. Karena nilai ibadah terletak pada fokusnya, maka seharusnya gereja menjadikan semua elemen kegerejaan sebagai penolong jemaat

35 Andreas J. Kostenberger, Encountering John: The Gosple in Historical, Literary, and Theological Perspective (Kindle version; Grand Rapids: Baker, 1999), loc. 386. 
berfokus pada Yesus. Meskipun ibadah bukanlah upacara kaku, tetapi ibadah juga bukan wahana entertainment jemaat. Karena itu, gereja tidak seharusnya berfokus pada kepuasan jemaat, tetapi bagaimana menolong jemaat berfokus pada Yesus dan mengalami kasih-Nya melalui tiap-tiap ibadah yang diselenggarakan. Ibadah hanya bernilai bila fokus ibadah ialah Yesus. Maka, sebuah ibadah tanpa Yesus, semegah dan semeriah serta sehebat apapun, tetap tidak ada nilainya.

\section{KEPUSTAKAAN}

Blomberg, Craig L., The Historical Reliability of the Gospel, $2^{\text {nd }}$ edition; Downers Grove: IVP, 2007.

Brown, Raymond E., The Gospel According to John I-XII, AB; New Haven: Yale, 2008.

Carson, D.A., The Gospel Accoding to John, PNTC; Grand Rapids: Eerdmans, 1991.

, Kesalahan-Kesalahan Eksegetis, Terjemahan Lanna Wahyuni; Surabaya: Momentum, 2009.

, "Understanding Misunderstandings in the Fourth Gospel," TynB 33, 1982 : 59-91.

Craigie, Peter C., The Book of Deuteronomyeronomy, NICOT; Grand Rapids: Eerdmans, 1976.

Handoko, Yakub Tri, Diktat Kuliah Injil Yohanes, Pacet: STTIAA, 2005.

Kostenberger, Andreas J., Encountering John: The Gosple in Historical, Literary, and Theological Perspective, Kindle version; Grand Rapids: Baker, 1999. , John, BECNT; Grand Rapids: Baker, 2004. 
150 Yesus Sebagai Penggenap Tempat Ibadah dalam Injil Yohanes

Patterson, R. D. and Hermann J. Austel, “1 \& 2 Kings," Expositor's Bible Commentary 4, Gen.ed. Frank E. Gaebelein; Grand Rapids: Zondervan, 1988.

Morris, Leon, The Gospel According to John, NICNT; Grand Rapids: Eerdmans, 1995.

Ridderbos, Herman, Injil Yohanes: Suatu Tafsiran Theologis, Terjemahan Lanna Wahyuni; Surabaya: Momentum, 2012.

Sandmel, Samuel, "Parallelomania," JBL 81, 1962 : 2-13

Sailhamer, John H., "Genesis," in Expositor's Bible Commentary 2, Gen.Ed. Frank E. Gaebelein; Grand Rapids: Zondervan, 1990.

Wenham, Gordon J., Genesis 1-15, WBC; Dallas: Word, 1987. 